\title{
Formations of calcium carbonate minerals by bacteria and its multiple applications
}

\author{
Periasamy Anbu, Chang-Ho Kang, Yu-Jin Shin and Jae-Seong So ${ }^{*}$
}

*Correspondence: sjaeseon@inha.ac.kr

Department of Biological Engineering, Inha University, Incheon 402-751, Republic of Korea

\begin{abstract}
Biomineralization is a naturally occurring process in living organisms. In this review, we discuss microbially induced calcium carbonate precipitation (MICP) in detail. In the MICP process, urease plays a major role in urea hydrolysis by a wide variety of microorganisms capable of producing high levels of urease. We also elaborate on the different polymorphs and the role of calcium in the formation of calcite crystal structures using various calcium sources. Additionally, the environmental factors affecting the production of urease and carbonate precipitation are discussed. This MICP is a promising, ecofriendly alternative approach to conventional and current remediation technologies to solve environmental problems in multidisciplinary fields. Multiple applications of MICP such as removal of heavy metals and radionuclides, improve the quality of construction materials and sequestration of atmospheric $\mathrm{CO}_{2}$ are discussed. In addition, we discuss other applications such as removal of calcium ions, PCBs and use of filler in rubber and plastics and fluorescent particles in stationary ink and stationary markers. MICP technology has become an efficient aspect of multidisciplinary fields. This report not only highlights the major strengths of MICP, but also discusses the limitations to application of this technology on a commercial scale.
\end{abstract}

Keywords: Biomineralization, Calcite, $\mathrm{CO}_{2}$ sequestration, MICP, Urease, Urea hydrolysis

\section{Background}

Biomineralization is the chemical alteration of an environment by microbial activity that results in the precipitation of minerals (Stocks-Fischer et al. 1999; Barkay and Schaefer 2001; Phillips et al. 2013). In nature, biomineralization is a widespread phenomenon leading to the formation of more than 60 different biological minerals (Sarikaya 1999) that exists as extracellularly inorganic crystals (Dhami et al. 2013a) or intracellularly (Konishi et al. 2006; Yoshida et al. 2010). Extracellular mineralization syntheses (for e.g., carbonate precipitation) from all groups of living organisms are widespread and well known phenomena (Lowenstam 1981). Most crystals formed through biomineralization consist of inorganic minerals, but they may also contain trace elements of organic compounds, which can regulate the biomineralization process (Yoshida et al. 2010). There are three different mechanisms involved in the production of biominerals: (1) Biologically controlled mineralization consists of cellular activities that specifically direct the

(c) 2016 Anbu et al. This article is distributed under the terms of the Creative Commons Attribution 4.0 International License (http:// creativecommons.org/licenses/by/4.0/), which permits unrestricted use, distribution, and reproduction in any medium, provided you give appropriate credit to the original author(s) and the source, provide a link to the Creative Commons license, and indicate if changes were made. 
formation of minerals (Lowenstam and Weiner 1989; Benzerara et al. 2011; Phillips et al. 2013). In this process, organisms control nucleation and growth of minerals. The minerals are directly synthesized at a specific location within or on the cell, but only under certain conditions. (2) Biologically influenced mineralization is the process by which passive mineral precipitation is caused by the presence of cell surface organic matter such as extracellular polymeric substances associated with biofilms (Benzerara et al. 2011; Phillips et al. 2013). (3) Biologically induced mineralization is the chemical modification of an environment by biological activity that results in supersaturation and the precipitation of minerals (Lowenstam and Weiner 1989; Stocks-Fischer et al. 1999; De Muynck et al. 2010; Phillips et al. 2013).

\section{Microbially induced calcite precipitation}

Microbially induced calcite precipitation (MICP) refers to the formation of calcium carbonate from a supersaturated solution due to the presence of their microbial cells and biochemical activities (Bosak 2011). During MICP, organisms are able to secrete one or more metabolic products $\left(\mathrm{CO}_{3}{ }^{2-}\right)$ that react with ions $\left(\mathrm{Ca}^{2+}\right)$ in the environment resulting in the subsequent precipitation of minerals. Previously, the formation of calcium carbonate precipitation was proposed to occur via different mechanisms such as photosynthesis (Thompson and Ferris 1990; McConnaughey and Whelan 1997), urea hydrolysis (Stocks-Fischer et al. 1999; De Muynck et al. 2010; Dhami et al. 2013a), sulfate reduction (Castanier et al. 1999; Warthmann et al. 2000; Hammes et al. 2003a), anaerobic sulfide oxidation (Warthmann et al. 2000), biofilm and extracellular polymeric substances (Kawaguchi and Decho 2002; Arias and Fernandez 2008). However, the precipitation of calcium carbonate by bacteria via urea hydrolysis is the most widely used method (Hammes and Verstraete 2002; DeJong et al. 2010; De Muynck et al. 2010).

The ability of urease (urea amidohydrolase; EC 3.5.1.5) to induce carbonate precipitation in microorganisms has already been discussed by several researchers (Hammes et al. 2003a; Burbank et al. 2012; Li et al. 2013; Stabnikov et al. 2013). Urease activity is found in a wide range of microorganisms, but some strains produce particularly high levels of urease (Table 1). For example, Sporosarcina pasteurii (formerly Bacillus pasteurii) is a soil, non-pathogenic and endospore producing bacteria with an optimum $\mathrm{pH}$ for growth of 9.0 that can tolerate extreme conditions. Accordingly, many researchers have extensively studied use of this strain for MICP (Bang et al. 2001; Hammes et al. 2003a; Mitchell and Ferris 2006; Achal et al. 2009a; Okwadha and Li 2010; Tobler et al. 2011; Cuthbert et al. 2012; Qabany et al. 2012; Gorospe et al. 2013). Additionally, Achal et al. (2009a) developed a mutant strain (BP-M-3) of Sporosarcina pasteurii MTCC 1761 that produced an enhanced level of urease activity and calcite precipitation compared to the wild type. Some pathogenic bacteria such as Helicobacter pylori, Proteus vulgaris, Staphylococcus aureus and Pseudomonas aeruginosa also produce urease, during urinary infection and are involved in the formation of intracellular urinary stones (Hesse and Heimbach 1999; Stabnikov et al. 2013).

The calcium carbonate $\left(\mathrm{CaCO}_{3}\right)$ precipitation process is a straightforward and easily controllable mechanism of MICP that can produce high concentrations of $\mathrm{CaCO}_{3}$ in short period of time (Dhami et al. 2013a). Urease influences the chemical process associated with the formation of biominerals through four different parameters (Hammes 
Table 1 Urease producing bacteria from various sources and amount of urease activity and calcite precipitation

\begin{tabular}{|c|c|c|c|c|}
\hline Bacteria & Isolation site & $\begin{array}{l}\text { Urease } \\
\text { activity }\end{array}$ & $\begin{array}{l}\text { Calcite } \\
\text { precipitation }\end{array}$ & References \\
\hline Bacillus sp. CR2 & Mine tailing soil Urumqi, China & $432 \mathrm{U} / \mathrm{ml}$ & $\begin{array}{l}2.32 \mathrm{mg} / \text { cell mass } \\
(\mathrm{mg})\end{array}$ & $\begin{array}{l}\text { Achal and Pan } \\
\text { (2014) }\end{array}$ \\
\hline L. sphaericus CH5 & $\begin{array}{l}\text { Abandoned express way } \\
\text { and abandoned mining } \\
\text { sites, Gangwondo, Korea }\end{array}$ & - & $980 \mathrm{mg} / 100 \mathrm{ml}$ & $\begin{array}{l}\text { Kang et al. } \\
\text { (2014a) }\end{array}$ \\
\hline Sporosarcinapasteurii & Phenotypic mutant strain & $550 \mathrm{U} / \mathrm{ml}$ & - & $\begin{array}{l}\text { Achal et al. } \\
\text { (2009a) }\end{array}$ \\
\hline B. pasteurii NCIM 2477 & $\begin{array}{l}\text { Culture obtained from NCIM, } \\
\text { Pune, India }\end{array}$ & $18 \mathrm{U} / \mathrm{ml}$ & - & $\begin{array}{l}\text { Sarada et al. } \\
\text { (2009) }\end{array}$ \\
\hline K. flava CR1 & Mining ore soil, Urumqi, China & $472 \mathrm{U} / \mathrm{ml}$ & - & Achal et al. (2011) \\
\hline B. megateriumSS3 & $\begin{array}{l}\text { Calcareous soil, Andhra } \\
\text { Pradesh, India }\end{array}$ & $690 \mathrm{U} / \mathrm{ml}$ & 187 mg/100 ml & $\begin{array}{l}\text { Dhami et al. } \\
\qquad(2013 b, 2014)\end{array}$ \\
\hline B. thuringiensis & $\begin{array}{l}\text { Calcareous soil, Andhra } \\
\text { Pradesh, India }\end{array}$ & $620 \mathrm{U} / \mathrm{ml}$ & $167 \mathrm{mg} / 100 \mathrm{ml}$ & $\begin{array}{l}\text { Dhami et al. } \\
\text { (2013b) }\end{array}$ \\
\hline Halomonassp. SR4 & Mine tailing, China & $374.5 \mathrm{U} / \mathrm{ml}$ & - & $\begin{array}{l}\text { Achal et al. } \\
\qquad(2012 a, b, c)\end{array}$ \\
\hline
\end{tabular}

and Verstraete 2002) such as $\mathrm{pH}$, dissolved inorganic carbon (DIC) concentrations, calcium concentrations and the availability of nucleation sites. The first three parameters influence the carbonate ions concentration $\left(\mathrm{CO}_{3}{ }^{2-}\right)$ (i.e., saturation state), while the last parameter (i.e., availability of nucleation sites) is very important for stable and continuous calcium carbonate formation (Phillips et al. 2013). In the biomineralization process, bacteria serve as nucleation sites, through which calcium carbonate precipitates with the bacteria. All of these parameters greatly affect either the ureolytic activity or $\mathrm{CaCO}_{3}$ crystal formation. Bacterial cell surfaces have negatively charged groups that act as scavengers for divalent cations (e.g. $\mathrm{Ca}^{2+}, \mathrm{Mg}^{2+}$ ) by binding them onto their cell surfaces at neutral $\mathrm{pH}$, which make ideal nucleation sites for calcite deposition (Ferris et al. 1996; Stocks-Fischer et al. 1999; Ramachandran et al. 2001). However, $\mathrm{Ca}^{2+}$ ions can bind more frequently onto the negatively charged cell surface of bacteria than $\mathrm{Mg}^{2+}$ due to their having greater power for ionic selectivity (Wold 1994; Sanchez-Roman et al. 2007). Subsequently, the bound cation (metal ions) reacts with anions (carbonate) to form calcium carbonate in an insoluble form (Fig. 1). Bacterial cells are very important for the precipitation of $\mathrm{CaCO}_{3}$, because the bacteria provide nucleation sites (heterogeneous nucleation) and affect the specific types of minerals formed (Douglas and Beveridge 1998; Rodriguez-Navarro et al. 2012).

\section{Mechanism of calcite precipitation}

Urease catalyzes the hydrolysis of urea into ammonium and carbonate. In this reaction, one mole of urea is hydrolyzed to one mole of ammonia and one mole of carbamic acid (Eq. 1), which is spontaneously hydrolyzed to another one mole of ammonia and carbonic acid (Eq. 2) (Stocks-Fischer et al. 1999; Burne and Chen 2000; Hammes et al. 2003a).

$$
\mathrm{CO}\left(\mathrm{NH}_{2}\right)_{2}+\mathrm{H}_{2} \mathrm{O} \stackrel{\text { Microbialurease }}{\longrightarrow} \mathrm{NH}_{2} \mathrm{COOH}+\mathrm{NH}_{3}
$$




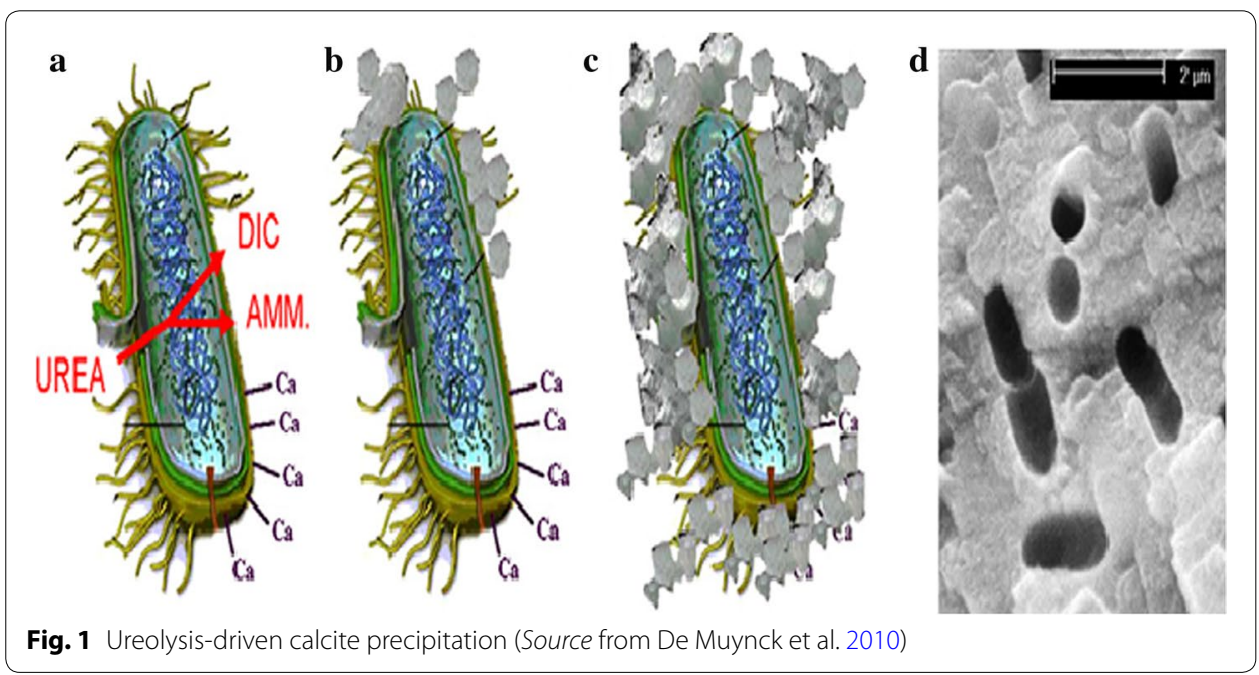

$\mathrm{NH}_{2} \mathrm{COOH}+\mathrm{H}_{2} \mathrm{O} \stackrel{\text { Spontaneous }}{\longrightarrow} \mathrm{NH}_{3}+\mathrm{H}_{2} \mathrm{CO}_{3}$

These two products $\left(\mathrm{NH}_{3}\right.$ and $\left.\mathrm{H}_{2} \mathrm{CO}_{3}\right)$ are further equilibrated in water to form bicarbonate (Eq. 3) and two moles of ammonium and two moles of hydroxide ions (Eq. 4). The hydroxide ions result in an increase of $\mathrm{pH}$, which can shift the bicarbonate equilibrium, resulting in the formation of carbonate ions (Fujita et al. 2008) (Eq. 5). This shift can then precipitate the metal ions. The generation of $\mathrm{NH}_{4}{ }^{+}$increases the local $\mathrm{pH}$ and the reaction continues spontaneously to form calcium carbonate (Ferris et al. 1996; Mitchell and Ferris 2005).

$$
\begin{aligned}
& \mathrm{H}_{2} \mathrm{CO}_{3} \leftrightarrow \mathrm{HCO}_{3}^{-}+\mathrm{H}^{+} \\
& 2 \mathrm{NH}_{3}+2 \mathrm{H}_{2} \mathrm{O} \leftrightarrow 2 \mathrm{NH}_{4}^{+}+2 \mathrm{OH}^{-} \\
& \mathrm{HCO}_{3}^{-}+\mathrm{H}^{+}+2 \mathrm{OH}^{-} \leftrightarrow \mathrm{CO}_{3}^{2-}+2 \mathrm{H}_{2} \mathrm{O}
\end{aligned}
$$

$\mathrm{CaCO}_{3}$ precipitation occurs at the bacterial cell surface if there are sufficient concentration of $\mathrm{Ca}^{2+}$ and $\mathrm{CO}_{3}{ }^{2-}$ in solution (Fig. 1) (Qian et al. 2010) (Eqs. 6, 7)

$$
\begin{aligned}
& \mathrm{Ca}^{2+}+\text { Bacterial cell } \rightarrow \text { Cell- } \mathrm{Ca}^{2+} \\
& \mathrm{Cell}-\mathrm{Ca}^{2+} \mathrm{CO}_{3}^{2-} \rightarrow \text { Cell- } \mathrm{CaCO}_{3}
\end{aligned}
$$

\section{Different polymorphs and their effects in various calcium sources}

Biomineralization can lead to produce different phases of $\mathrm{CaCO}_{3}$ anhydrous polymorphs such as calcite, aragonite and vaterite, as well as hydrated crystalline phases such as monohydrocalcite $\left(\mathrm{CaCO}_{3} \cdot \mathrm{H}_{2} \mathrm{O}\right)$ and hexahydrocalcite or ikaite $\left(\mathrm{CaCO}_{3} \cdot 6 \mathrm{H}_{2} \mathrm{O}\right)$ and amorphous calcium carbonate (ACC) (Krumbein 1979; Hammes et al. 2003a; Wei et al. 2003; Ben Chekroun et al. 2004; Xu et al. 2006; Chen et al. 2009; Sanchez-Navas et al. 2009; Gebauer et al. 2010; Dhami et al. 2013b). Among these, calcite and vaterite are the most common polymorphs (Gonzalez-Munoz et al. 2010; Rodriguez-Navarro et al. 2007; 
Dhami et al. 2013b, 2014). Vaterite is a minor, metastable and transitional phase during calcite formation (Tourney and Ngwenya 2009). Calcite is the most thermodynamically stable polymorph of $\mathrm{CaCO}_{3}$ and the primary product of $\mathrm{CaCO}_{3}$ in many MICPs (Spanos and Koutsoukos 1998; Stocks-Fischer et al. 1999; Okwadha and Li 2010; Ganendra et al. 2014). In contrast, Rivadeneyra et al. (1996) reported that aragonite is the predominant crystal formed by Deleya halophila. Chen et al. (2009) found that $\mathrm{CaCO}_{3}$ produced by Proteus mirabilis has an unusual morphology and structure, consisting of vaterite hollow spheres. Calcite and vaterite are different solid state phases of $\mathrm{CaCO}_{3}$. The precipitation of $\mathrm{CaCO}_{3}$ by mixing concentrated $\mathrm{Ca}^{2+}$ and $\mathrm{CO}_{3}{ }^{2-}$ solution involves at least three steps namely formation of amorphous calcium carbonate which is a form of $\mathrm{CaCO}_{3}$ with low stability and high solubility, transformation of amorphous $\mathrm{CaCO}_{3}$ into vaterite, and subsequent transformation of thermodynamically unstable vaterite into stable calcite (Spanos and Koutsoukos 1998; Wei et al. 2003; Shen et al. 2006; Hua et al. 2007). Pouget et al. (2009) have proposed the template controlled the initial stages of $\mathrm{CaCO}_{3}$ formation i.e. before transformation of ACC into vaterite and calcite. The initial stages of $\mathrm{CaCO}_{3}$ precipitation start with the formation of prenucleation clusters, aggregation of the clusters to form ACC nanoparticles and association of the nanoparticles with the template surface to initiate the ACC growth.

Different calcium sources induce crystal with different shapes (Fig. 2), with a rhombohedral shape induced by calcium chloride being characteristic of the most stable form of $\mathrm{CaCO}_{3}$ (calcite) (De Yoreo and Vekilov 2003; Favre et al. 2009; Gorospe et al. 2013). Other calcium sources also induced different shape of $\mathrm{CaCO}_{3}$ (Fig. 2). For example, calcium acetate induces a lettuce like or lamellar shape, (a metastable form of $\mathrm{CaCO}_{3}$ ) composed of vaterite, while calcium lactate and calcium gluconate induces a more complex form with packing that leads to growth of vaterite with a spherical shape (Tai and Chen 1998). The morphological differences in the crystal formation may be strain-specific, owing to differences in urease activity (Hammes et al. 2003a; Park et al. 2010). Alternatively, these differences could reflect the specific EPS protein produced by different bacterial types controlling calcite or aragonite polymorph selection (Kawaguchi and Decho, 2002), because EPS proteins may specifically bind $\mathrm{Ca}^{2+}$ and promote carbonate precipitation (Dhami et al. 2013b). The composition of the growth media or culture may also affect the crystal morphology because different bacterial species are able to precipitate different amounts, shapes and types of carbonate crystals from the same synthetic medium (Ferrer et al. 1988; Hammes and Verstraete 2002; Dhami et al. 2013b). Examination of the cells by electron microscopy reveals that calcium carbonate precipitation is closely associated with bacterial cells (Fig. 2).

Even though, many researchers have used different calcium sources for the induction of $\mathrm{CaCO}_{3}$ precipitation, calcium chloride is the best source for induction of calcite precipitation (Achal and Pan 2014). The effects of different calcium salts on stabilization of sand particles by bioconsolidation were investigated and blocks were formed in all samples treated by biocementation using various calcium sources (Fig. 3); however, the sand blocks collapsed after the Petridish demolded in the control samples, because dead cells were used (Gorospe et al. 2013). Our group has developed a simple method for testing impermeability to determine the efficiency of MICP. Specifically, the degree of 

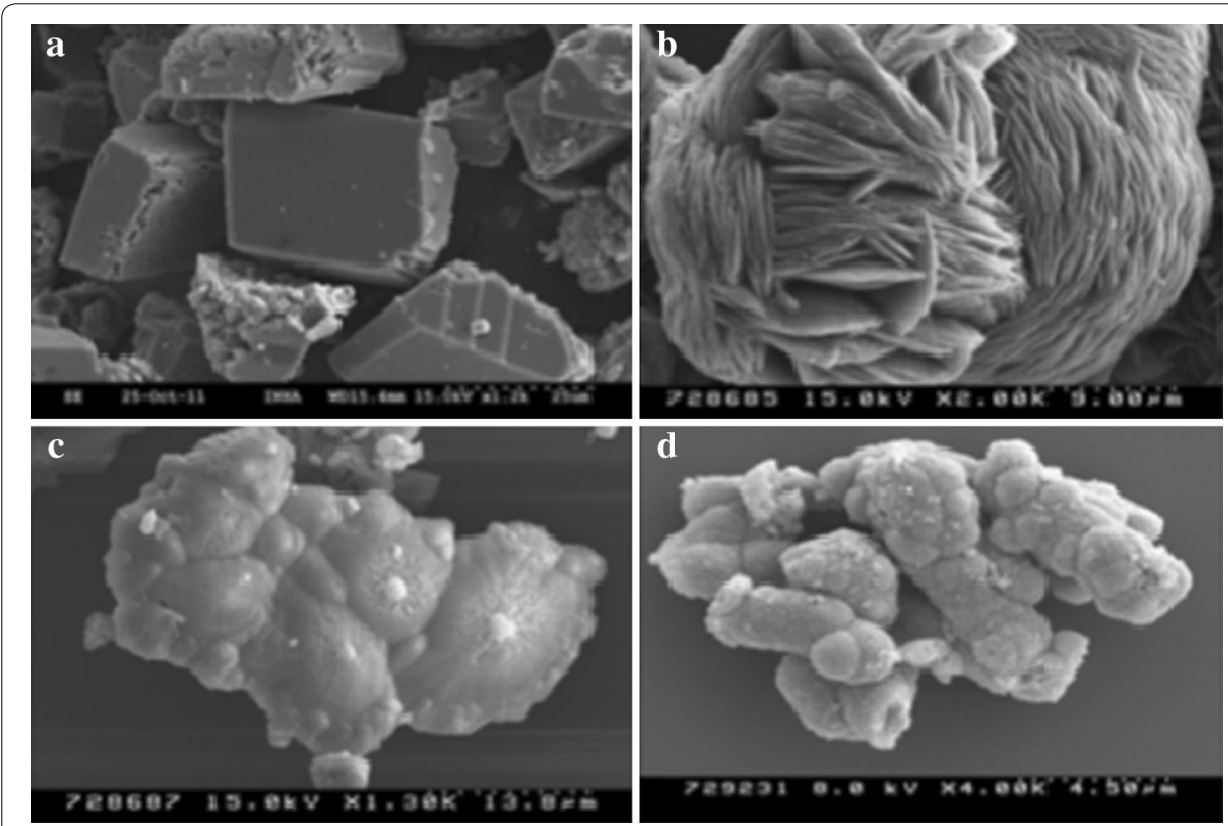

Fig. 2 Scanning electron micrographs showing the effects of different calcium sources on the shape of the crystals formed. a Calcium chloride, b calcium acetate, c calcium lactate, $\mathbf{d}$ calcium gluconate (Source from Gorospe et al. 2013)
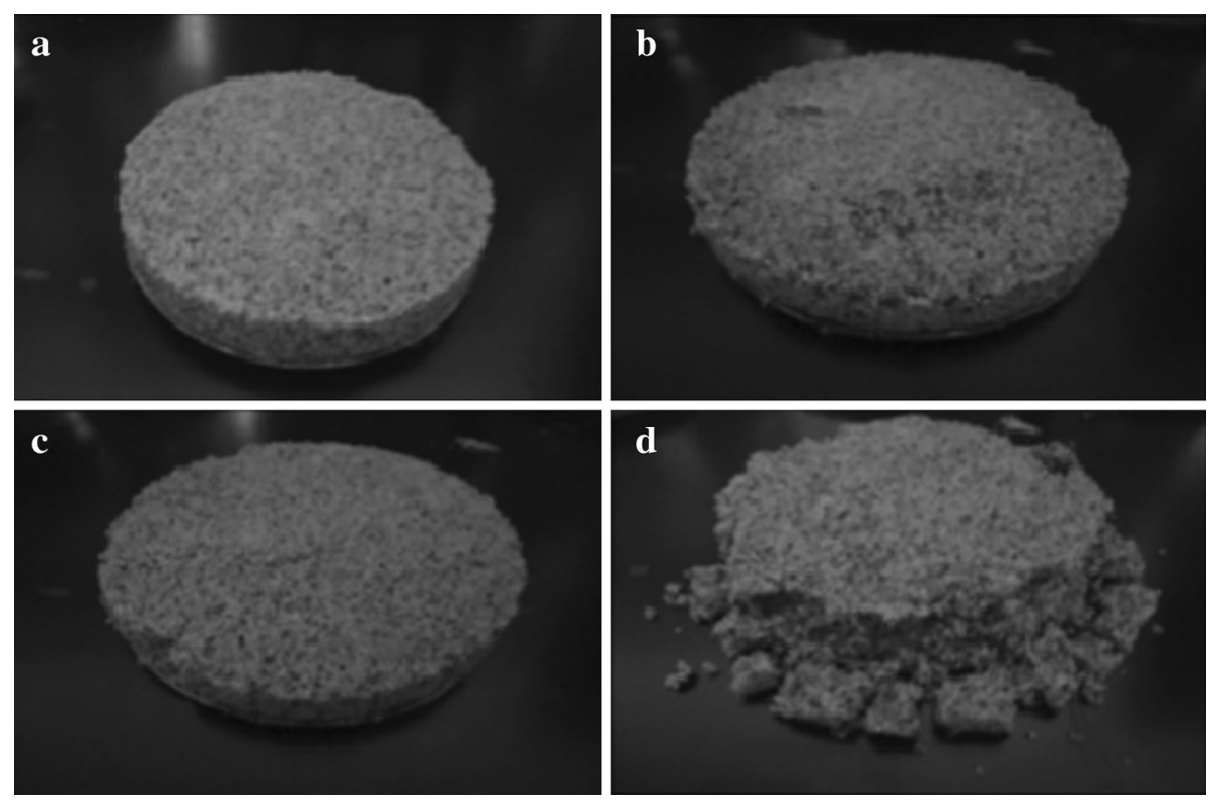

Fig. 3 Bioconsolidated sand blocks made from different calcium salts. a calcium chloride, $\mathbf{b}$ calcium acetate, c calcium lactate, d control (Source from Gorospe et al. 2013)

impermeability was determined by measuring the migration distance of crystal violet. The calcium carbonate crystals are deposited between sand particles, resulting in plugging (Fig. 4). 


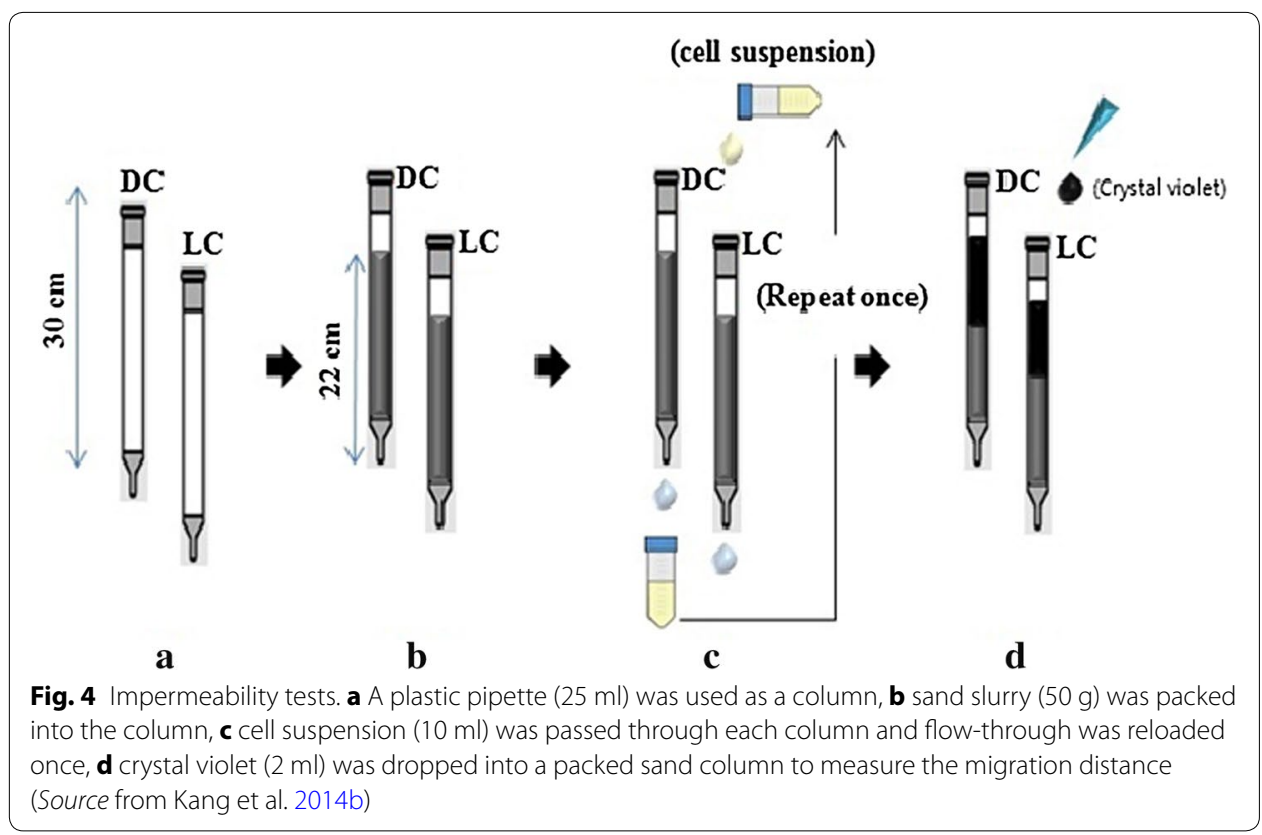

\section{Factors affecting the efficiency of MICP}

The activity of urease and the amount of $\mathrm{CaCO}_{3}$ precipitation are based on several environmental factors. Indeed, many factors affect urease activity and calcium precipitation including bacteria type, bacteria cell concentrations, $\mathrm{pH}$, temperature, urea and calcium concentrations (Hammes and Verstraete 2002; Mortensen et al. 2011; Ng et al. 2012; Qabany et al. 2012).

\section{Bacteria type}

The type of bacteria is essential to the production of urease capability. Many urease producing bacteria have been investigated, including Aerobacter aerogenes, B. megaterium, B. subtilis, Bacillus sp. CR2, B. thuringiensis, D. halophila, Halmonas eurihalina, Helicobacter pylori, Kocuria flava CR1, L. sphaericus CH5, Methylocystis parvum, Myxococcus xanthus, Proteus mirabilis, Pseudomonas denitrificans, Spoloactobacillus sp., Sporosarcina ginsengisoli and Sporosarcina pasteurii (Perez-Perez et al. 1994; Rivadeneyra et al. 1996, 1998; Stocks-Fischer et al. 1999; Ben Chekroun et al. 2004; Karatas et al. 2008; Chen et al. 2009; Achal et al. 2011, 2012b; Dhami et al. 2013b, 2014; Gorospe et al. 2013; Achal and Pan 2014; Ganendra et al. 2014; Kang et al. 2014a). Different types of bacteria were found to be able to produce various amounts of urease and calcium carbonate precipitation (Table 1). Bacillus group is a common type of bacteria used for the production of urease and calcite precipitation. For example, Sporosarcina pasteuriiis the main organism used for multiple applications such as remediation of heavy metals and radionuclides, crack remediation in concrete and soil improvement (Whiffin et al. 2007; Sarada et al. 2009; Gorospe et al. 2013; Lauchnor et al. 2013; Li et al. 2013), while $B$. megaterum is used to enhance the concrete strength and durability of building materials and structures (Siddique et al. 2008; Soon et al. 2013; Dhami et al. 2014). L. sphaericus CH-5 and K. flava CR1 are used for the removal of cadmium and lead, respectively, from 
the environment (Achal et al. 2012a; Kang et al. 2014a). Achal et al. (2009a) developed a mutant strain of Sporosarcina pasteurii capable of producing more urease activity and $\mathrm{CaCO}_{3}$ precipitation than the wild strain of Sporosarcina pasteurii MTCC 1761.

\section{Bacteria cell concentration}

High concentrations of bacterial cells (from $10^{6}$ to $10^{8}$ cells) increase the amount of calcite precipitation by MICP, via increases in the urease concentration for urea hydrolysis (Okwadha and Li 2010). Therefore, urea hydrolysis has a direct relationship with bacterial cell concentrations (Ng et al. 2012). Stocks-Fischer et al. (1999) reported that bacterial cells served as nucleation sites for $\mathrm{CaCO}_{3}$ precipitation, because the availability of the nucleation site is very important for calcite precipitations (Ng et al. 2012). StocksFischer et al. (1999) compared the efficiency of microbially induced $\mathrm{CaCO}_{3}$ precipitation with chemically induced precipitation at $\mathrm{pH} 9.0$ and confirmed that $98 \%$ of the initial $\mathrm{Ca}^{2+}$ concentrations were precipitated microbially, but only 35 and $54 \%$ precipitated chemically in water and medium, respectively. This difference occurred because the bacterial cells provide the nucleation sites for $\mathrm{CaCO}_{3}$ precipitation and create an alkaline environment for the induction of further growth of calcite (Stocks-Fischer et al. 1999).

$\mathrm{pH}$

Calcite precipitation is influenced by $\mathrm{pH}$, because the urease enzyme will only be active at $\mathrm{pH}$ values specific for urea hydrolysis. Many investigators have reported that the optimum $\mathrm{pH}$ for urease is 8.0, above which the enzyme activity decreases (Stocks-Fischer et al. 1999; Gorospe et al. 2013). A high pH is very important for ammonia production by urea hydrolysis. Aerobic bacteria release $\mathrm{CO}_{2}$ via cell respiration, which is paralleled by an increase in $\mathrm{pH}$ due to ammonia production ( $\mathrm{Ng}$ et al. 2012). If the $\mathrm{pH}$ levels become low, the carbonate will tend to dissolve rather than precipitate (Loewenthal and Marais 1978). Most calcite precipitation occurs under alkaline conditions from $\mathrm{pH} 8.7$ to 9.5 (Stocks-Fischer et al. 1999; Ferris et al. 2003; Dupraz et al. 2009), but Mobley et al. (1995) found that the acid urease and optimum pH were nearly neutral. Stabnikov et al. (2013) recently investigated whether halophilic and alkaliphilic urease producing bacteria are active at high concentrations of inorganic salt and $\mathrm{pH}$ above 8.5 and the conditions suitable for manufacturing biocement.

\section{Temperature}

Like other enzymatic reactions, the catalysis of urea by urease is temperature dependent. The optimum temperature for most ureases ranges from 20 to $37^{\circ} \mathrm{C}$ (Mitchell and Ferris 2005; Okwadha and Li 2010) and the optimum range of the enzymatic reaction depends on environmental conditions and concentration of reactants in the system. Mitchel and Ferris (2005) reported that the urease activity increased by about 5 times and 10 times when the temperature increased from 15 to $20^{\circ} \mathrm{C}$ and 10 to $20^{\circ} \mathrm{C}$, respectively. Ferris et al. (2003) investigated the kinetic rate of urease and the temperature dependence of ureolytic $\mathrm{CaCO}_{3}$ precipitation by $\mathrm{B}$. pasteurii at 10 and $20{ }^{\circ} \mathrm{C}$ in artificial ground water. Dhami et al. (2014) found that urease was completely stable at $35^{\circ} \mathrm{C}$, but when the temperature increased to $55^{\circ} \mathrm{C}$ the enzyme activity decreased by almost $47 \%$. 


\section{Urea and $\mathrm{Ca}^{+}$concentrations}

The hydrolysis of urea by urease not only increases the $\mathrm{pH}$, but also uses it as a nitrogen and energy source (Mobley and Hausinger 1989; Achal et al. 2009a). It is possible that individual microorganisms can produce ammonia as a result of enzymatic hydrolysis of urea to create an alkaline micro-environment around the cell and increase the $\mathrm{pH}$, subsequently inducing the $\mathrm{CaCO}_{3}$ precipitation (Stocks-Fischer et al. 1999). Microbial cell surfaces have negatively charged and act as scavengers for cations, particularly $\mathrm{Ca}^{2+}$, in aquatic environments by binding them onto their cell surfaces; accordingly, microorganisms act as ideal crystal nucleation sites (Stocks-Fischer et al. 1999; Ramachandran et al. 2001). Therefore, the ideal calcium source and concentration is important for $\mathrm{CaCO}_{3}$ precipitation. However, high concentrations of urea and $\mathrm{CaCl}_{2}$ (above $0.5 \mathrm{M}$ ) decrease the efficiency of calcite precipitation (Okwadha and Li 2010), which increased efficiency was observed at low concentrations (0.05-0.25 M). De Muynck et al. (2010) reported that the best urea and $\mathrm{CaCl}_{2}$ concentrations for calcite precipitation are 0.5 and $0.25 \mathrm{M}$, respectively. Actually, the $\mathrm{Ca}^{2+}$ is not likely utilized by metabolic processes, but accumulates outside the cell, where it is readily available for $\mathrm{CaCO}_{3}$ precipitation (Silver et al. 1975). Okwadha and $\mathrm{Li}$ (2010) reported that the amount of $\mathrm{CaCO}_{3}$ precipitation depends more on $\mathrm{Ca}^{2+}$ concentrations than urea concentrations. Hammes et al. (2003a) investigated the importance of $\mathrm{Ca}^{2+}$ for urease activity and found that enzyme activity increased by tenfold in the presence of $\mathrm{Ca}^{2+}$ when compared than the absence of $\mathrm{Ca}^{2+}$. Recently, Achal and Pan (2014) studied the calcium precipitation from Bacillus sp. CR2 when different calcium sources were used in nutrient broth containing urea. Among the various calcium sources used, calcium chloride is best for the production of calcite as well as the higher urease activity.

\section{Isolation of ureolytic bacteria from various sources}

The main task of the MICP technique is isolation and selection of potent urease producing bacteria. To promote ureolysis-driven calcite precipitation, the microorganisms should produce a sufficient amount of urease enzyme. Therefore, many investigators have isolated ureolytic microorganisms from various sources (Dejong et al. 2006; Hammes et al. 2003a; Achal and Pan 2014; Kang et al. 2014a) (Table 1). Ureolytic microorganisms that can induce $\mathrm{CaCO}_{3}$ precipitation have been studied for multiple applications such as remediation, consolidation and cementation (Ivanov and Chu 2008; De Muynck et al. 2010; Phillips et al. 2013).

Hammes et al. (2003a) reported that $\mathrm{CaCO}_{3}$ precipitating strains were isolated from garden and landfill soil from Ghent, Belgium. Achal et al. (2009a) developed a phenotypic mutant of Sporosarcina pasterurii by UV irradiation and compared it with the wild type strain MTCC 1761. The mutant strain (Bp-M3) was able to grow at higher pH (up to 11 ) than the wild type (up to 10) and to produce high urease activity and calcite precipitation. The increase in $\mathrm{pH}$ is very important to enhancement of the urease activity and calcium carbonate precipitation. The urease producing bacteria Bacillus sp. CR2 was isolated from mine tailing soil of Urumgi, Xinjiang, China (Achal and Pan 2014), and several Sporosarcina species were isolated from nursery garden soil at Tsinghwa University, China (Li et al. 2013). Positive strains were identified by the pink color formed upon hydrolysis of urea in urea test agar plates. 
Dhami et al. (2013b) recently isolated the ureolytic bacterial strains from calcareous soil samples collected in Andhra Pradesh, India. Five positive strains (B. megaterium, B. thuringiensis, B. cereus, B. subtilis and L. fusiformis) were selected based on the urease activity, and calcite precipitation. However, $B$. megaterium produced highest urease activity $(690 \mathrm{U} / \mathrm{ml})$, and calcite precipitation $(187 \mathrm{mg} / 100 \mathrm{ml})$. Other urease producing bacteria were isolated from an abandoned express way and abandoned mining sites in Gangwondo, Korea (Kang et al. 2014a), four of which showed urease activity and calcite production. However, only two strains of Lysinibacillus sp. were able to produce high urease activity and calcite precipitation. The same group isolated another strain of urease producing bacteria, Sporosarcina pasteurii WJ-2 from abandoned express way sites, in Gangwondo, Korea (Unpublished data). Sarada et al. (2009) screened three different microorganisms for urease production and found that B. pasteurii could produce urease at levels approximately two-fold higher than other tested microorganisms. Some investigators have also revealed ureolytic activity in situ in natural soil and ground water systems (Nielsen et al. 1998; Fujita et al. 2008; Tobler et al. 2011).

All bacteria could produce various amounts of urease and calcite precipitation (Table 1), while some microorganisms could produce high levels of urease and were involved in the hydrolysis of urea (Achal et al. 2009a; Dhami et al. 2013b, 2014). The endospore forming bacteria Sporosarcina pasteurii ATCC 11859 and B. megaterium have been shown to produce high levels of urease and have therefore been extensively studied. The urease activity was determined by phenol-hypochloride assay (Natarajan 1995). One unit of urease is defined as the amount of enzyme hydrolyzing $1 \mu \mathrm{mol}$ urea/ min. Bachmeier et al. (2002) investigated the role of nickel ions in the active site of the urease enzyme for its functional activity and the structural integrity of the enzyme. They also demonstrated recombinant transformation of the B. pasteurii urease gene to Escherichia coli HB101 containing pBU11plasmid. However, the amount of calcite precipitation by recombinant strain E. coli HB101 was lower than that of the wild type (Bachmeier et al. 2002).

\section{MICP applications}

The MICP process is an effective and eco-friendly technology that can be applied to solve various environmental problems, including remediation of heavy metals and radionuclides, bioconsolidation, biocement, $\mathrm{CO}_{2}$ sequestration and other applications (De Muynck et al. 2010; Mitchell et al. 2010; Yoshida et al. 2010; Hamdan et al. 2011; Achal et al. 2012a, c).

\section{Removal of heavy metals and radionuclides}

\section{Removal of heavy metals}

Due to the rapid development of industrialization, heavy metal and radionuclide contaminants from industrial activities pose a major threat to the environment owing to their toxicity, non-biodegradability and persistent accumulation (Gazso 2001; Bahadir et al. 2007; Perez-Marin et al. 2008; Guo et al. 2010). Moreover, the heavy metals and radionuclides that accumulate in the environment create many health problems for humans and other living organisms. Some heavy metals are essential to human health in small quantities, but toxic in the large quantities released by industry (Guo et al. 2010; Fu 
and Wang 2011). For example, water sources contaminated by toxic heavy metals leaching from industrial wastes introduce heavy metals to plants, which are then ingested by animals that are subsequently consumed by humans. Indeed the ingestion of plant and animal based foods is the largest source of heavy metals exposure to humans (Radojevic and Bashkin 1999; Mulligan et al. 2001). The level of toxicity is based on the concentrations of the particular heavy metals; therefore, heavy metal ion contaminants are a very serious problem in the environment and their removal from contaminated soil and wastewater requires attention (Vullo et al. 2008).

Common heavy metals such as cadmium, chromium, cobalt, copper, arsenic, lead, nickel, selenium, silver, zinc, mercury, antimony, and thallium are naturally occurring, but become concentrated as a result of anthropogenic activities (Perez-Marin et al. 2008; Guo et al. 2010). Conventional treatments such as adsorption, chemical precipitation, electrochemical treatment, evaporation method, filtration, ion exchange, membrane technology, oxidation/reduction, and reverse osmosis (Kapoor and Viraraghavan 1995; Volesky 2001; Bai et al. 2008; Vullo et al. 2008; Wang and Chen 2009) have been used to remove heavy metals from contaminated environments. Unfortunately, these traditional methods often do not remove the metals successfully because they are ineffective, expensive, and consume high amounts of chemicals and energy (Fu and Wang 2011). In recent years, many biological treatments (using microorganisms) have been introduced to remove heavy metals from contaminated sites through phytoremediation, bioaccumulation, biocoagulation, bioleaching, biosorbents and bioimmobilization (Volesky 2001; Gadd 2000; Gazso 2001; Lloyd and Lovely 2001; Lin and Lin 2005; Achal et al. 2011). However, these methods are also not effective because they are expensive, time consuming and result in the release of immobilized or adsorbed heavy metals back to the environment (Achal et al. 2011). Therefore, alternative methods such as MICP are needed to remove the heavy metals effectively, economically and in an eco-friendly manner (Hamdan et al. 2011; Achal et al. 2012a, b). Several authors have reported that MICP has the potential to remediate heavy metals and radionuclides from the environment (Hamdan et al. 2011; Achal et al. 2012c).

Heavy metal toxicity affects the microbial growth and efficiency of MICP; therefore, several researchers have isolated metal tolerant microbes with ureolytic capability from various environments to improve the efficiency of the MICP process (Guo et al. 2010; Achal et al. 2011; Kang et al. 2014a). In MICP process, calcites can be incorporated heavy metals (e.g., $\mathrm{Pb}^{2+}$ ) onto their surfaces via substitution of suitable divalent cations $\left(\mathrm{Ca}^{2+}\right)$ in the calcite lattice (Eq. 8), after which these compounds are changed from soluble heavy metals to insoluble forms i.e., detoxify the heavy metals (Pan 2009; Achal et al. 2011). Li et al. (2013) reported that a few species of Sporosarcina and B. lentus urease producing bacteria were able to remove 88 to $99 \%$ of heavy metals after $48 \mathrm{~h}$ of incubation. SEM analyses showed evidence of the transformation of heavy metals into stable calcite and other crystal forms (Figs. 2, 5).

$$
\mathrm{Pb}^{2+}+\mathrm{OH}^{-}+\mathrm{HCO}_{3}^{-}=\mathrm{PbCO}_{3}+\mathrm{H}_{2} \mathrm{O}
$$



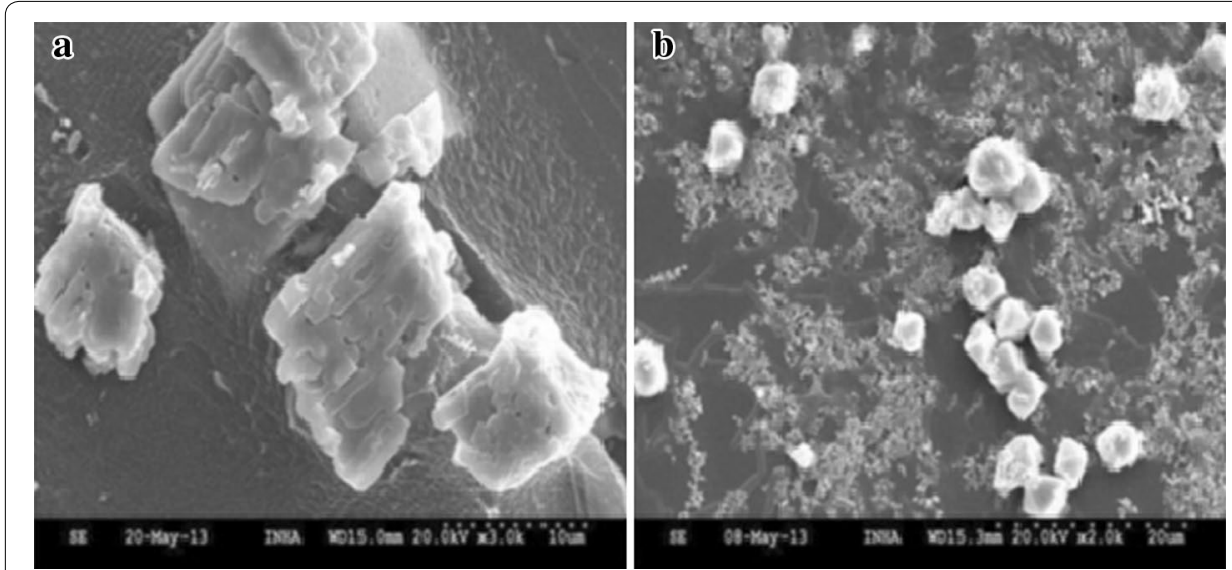

Fig. 5 Scanning electron micrograph showing the remediation of cadmium by L. sphaericus $\mathrm{CH}-5$. $\mathbf{a} \mathrm{CdCl}_{2}$, b $\mathrm{CdCO}_{3}$ (Source from Kang et al. 2014a)

\section{Copper}

Copper is naturally present in soil, air and water and an essential micronutrients for cell functions, but the ingestion of large quantities of copper has serious toxicological effects (Paulino et al. 2006; Achal et al. 2011). Achal et al. (2011) isolated the copper tolerant bacteria $K$. flava CR1 from a mining area in China, using the MICP process and achieved about $97 \%$ copper removal from the environment. Moreover, they found that the bacteria had high levels of urease activity, which was involved in removal of high concentrations of copper. The high concentration of copper primarily affects the bacterial growth, but it improves the copper removal rate by K. flava CR1 (Achal et al. 2011). Recently, Li et al. (2013) reported that the removal rate of copper by Sporosarcina koreensis UR47 was approximately $93 \%$, which was higher than that by Sporosarcina pasteurii ATCC 11859.

\section{Cadmium}

Cadmium is an extremely toxic metal commonly used in electroplating, in industrial paints, manufacture of batteries, construction and agriculture. Kang et al. (2014a) investigated the potential removal rate of cadmium ( $99.5 \%$ ) by MICP after $48 \mathrm{~h}$ in beef extract, peptone and urea (BPU) media (Fig. 5). Ma et al. (2009) reported that water borne heavy metals $(\mathrm{Cu}, \mathrm{Zn}$ and $\mathrm{Cd})$ were removed well by $\mathrm{CaCO}_{3}$-dominated red mud. Recently, another study also found that Terrabacter tumescens removed more than $99 \%$ of the cadmium from soil wastewater via MICP (Li et al. 2013).

\section{Chromium}

Chromium is common environmental pollutant in the environment, although trace levels of some forms of chromium such as $\mathrm{Cr}$ (III) in food and water and appear to be benign. However, $\mathrm{Cr}(\mathrm{VI})$ is highly mobile, toxic, soluble and carcinogenic (Kamaludeen et al. 2003). Many investigators have attempted to remove chromium from Cr-contaminated soil and water by phytoremediation and bioremediation (Chandra et al. 1997; Lytle et al. 1998; Jeyasingh and Philip 2005); however, these techniques release the immobilized or adsorbed heavy metals back into the soil or water. Using the MICP process, 
chromate can interact with $\mathrm{CaCO}_{3}$ in co-precipitated form and effectively remove chromium from Cr-contaminated sites (Hua et al. 2007; Achal et al. 2013). A few studies have shown the role of metal ions during the transformation process (Nassrallah-Aboukais et al. 1999; Wei et al. 2003). The process of transformation from vaterite to calcite, which is important to produce stable crystals, occurs via a spontaneous reaction through either simple contact with water or heating. Accordingly, if there are any metal ions on the surface of the vaterite, the transformation process may be delayed or stabilized (Nassrallah-Aboukais et al. 1999). However, the same authors reported that the transformation process is not delayed in the presence of $\mathrm{Cu}^{2+}$ on the surface of the vaterite. In contrast, Hua et al. (2007) reported that the transformation process was delayed or inhibited in the presence of $\mathrm{Cr}(\mathrm{VI})$.

\section{Lead}

Lead is the most prevalent heavy metal contaminant among environmental pollutants (Di Maio 2001). Removal of lead by currently available remediation methods such as biosorption and other techniques is ineffective and requires high volumes of reagents. Additionally, these methods are expensive, result in generation of toxic sludges and require a means of safe disposal (Suh et al. 1998; Pan et al. 2005; Wang and Chen 2009). Puyen et al. (2012) found that the lead and copper removal rate were 36.07 and $25.42 \%$, respectively, in response to the biosorption method in culture media by heavy metal tolerant Micrococcus luteus DE2008. In the MICP process, lead was bound with the MICP product (calcite), which was responsible for $\mathrm{Pb}$ immobilization and resulted in significantly reduced $\mathrm{Pb}$ levels in the environment (Achal et al. 2012a; Kang et al. 2015a). Very recently, Li et al. (2013) found that the potential removal rate of lead by Sporosarcina koreensis UR47 was nearly $100 \%$.

\section{Arsenic}

Arsenite (AsIII) is the most common and toxic arsenic species. Arsenite is highly mobile in soil and easily leached into groundwater (Achal et al. 2012b). Many researchers have used various bioremediation methods to remove arsenic from the environment (Yamamura et al. 2003; Fayiga et al. 2004; Kirk et al. 2004); however, these methods are ineffective because the immobilized or adsorbed heavy metals are again released into the environment. Achal et al. (2012b) isolated an arsenic tolerant bacteria Sporosarcina ginsengisoli CR5 and reported that its growth decreased when arsenic was present in the media. However, the strain was able to effectively remove about $96.3 \%$ of the arsenic after 7 days of cultivation in NBU media containing $50 \mathrm{mM} \mathrm{As(III).} \mathrm{Another} \mathrm{study}$ reported that about $96.9 \%$ of arsenic was removed from aqueous media containing only $40 \mathrm{mM}$ of As(III) (Aksornchu et al. 2008). The main advantage of using MICP for arsenic removal is that the product (carbonate metal complex) is insoluble and traps the arsenic, preventing it from being released back into the environment (Achal et al. 2012b).

\section{Removal of radionuclides}

The disposal of radionuclide wastewater from commercial nuclear plants is a major issues associated with nuclear waste management because it is highly toxic to the environment, particularly to human health (Ahmadpour et al. 2010). Many researchers have 
used various physico-chemical processes to remove radionuclides such as chemical precipitation, flocculation, ion exchange, membrane process, immobilization and adsorption (Mishra and Tiwary 1999; El-Kamash et al. 2006; Rawat et al. 2006; Rout et al. 2006; Omar et al. 2009). Fujita et al. (2008) investigated a pump and treat method, but found that it was ineffective at removal of radionuclides from the contaminated environment. Therefore, an alternative method of MICP involved cleaning up the radionuclides safely from the environment. The MICP method stimulates ureolytic microorganisms to promote $\mathrm{CaCO}_{3}$ precipitation, which in turn leads to promote co-precipitation of radionuclides by substitution of $\mathrm{Ca}^{2+}$ ion and formation of radionuclide carbonate minerals (Mitchell and Ferris 2006; Fujita et al. 2010).

\section{Strontium}

In living organisms, strontium is highly toxic and soluble; therefore, it can be readily passed through the food chain from contaminated soil or water. Additionally, strontium is capable of exerting long term health impacts due to its long half-life (28.8 years) (Singh et al. 2008). The mobility and carcinogenic effects of $\mathrm{Sr}$ affect groundwater usability (Lauchnor et al. 2013), and the conventional remediation techniques are expensive and ineffective (AbdEl-Sabour 2007). Strontium 90 exists in the environment as the $\mathrm{Sr}^{2+}$ ion, which has chemical similarity to $\mathrm{Ca}^{2+}$; therefore, $\mathrm{Sr}^{2+}$ can replace calcium ions in living systems (Singh et al. 2008; Achal et al. 2012c). Many researchers have successfully demonstrated the co-precipitation of ${ }^{90} \mathrm{Sr}^{2+}$ into calcite by substituting $\mathrm{Ca}^{2+}$ in calcite crystal through MICP effectively (Fujita et al. 2004; Smith et al. 2004; Mitchell and Ferris 2005; Achal et al. 2012c; Brookshaw et al. 2012). Warren et al. (2001) found that $95 \%$ of strontium was captured in the solid phase by MICP when Sporosarcina pasteuriiwas used. Achal et al. (2012c) isolated the Sr-resistant and urease producing bacteria Halomonas sp. SR4, and reported approximately $80 \%$ Sr removal from the soluble exchangeable fraction of aquifer quartz sand. Kang et al. (2014b) recently reported a similar removal rate of $\mathrm{Sr}$ from the soluble fraction of sand by Sporosarcina pasteurii WJ-2.

\section{Bioconsolidation of soil and sand}

In geotechnical engineering, bioconsolidation is involved in prevention or stabilization of erosion and increasing slope stability. Conventional techniques such as applying cement or chemicals are primarily used to improve soil; however these can lead to permanent soil and water contamination or air pollution (Khodadadi and Bilsel 2012). Additionally, these synthetic chemicals can be injected into the subsurface to bind sand grains together, increasing soil strength and stiffness. However, this method is expensive, difficult to distribute uniformly and introduces hazardous substances into the soil (DeJong et al. 2010). New construction on weak soil results in low strength and high compressibility (Huat 2006; Ng et al. 2012). Many investigators have successfully applied chemical grout to improve the soil (Karol 2003; Basha et al. 2005); however, the pH of the soil was modified, soil and ground water were contaminated, and the toxicity of the soil increased (DeJong et al. 2006). Therefore, an effective technique to improve soil quality is necessary. MICP has been investigated as an attractive method of grouting to improve the soil structure. Whiffin et al. (2007) reported that sand stabilization treatment to increase the bacterial adhesion to sand, before MICP treatment and reduction 
of porosity and improvement of strength of soil found positively in sand packed columns after MICP treatment.

The induction of $\mathrm{CaCO}_{3}$ precipitation binds sand grains together at the particle-particle contacts, which increases the strength and stiffness of the soil (DeJong et al. 2010; Mortensen et al. 2011; Gorospe et al. 2013). This method utilizes biochemical processes to improve the engineering properties of soil such as shear strength and impermeability (Chu et al. 2012; Kang et al. 2015b). Ivanov and Chu (2008) compared the cost of conventional chemical grouting with microbial grouting and found microbial grouting $\left(\$ 0.5-9 / \mathrm{m}^{3}\right.$ of soil) to be significantly less expensive than chemical grouting $\left(\$ 2-72 / \mathrm{m}^{2}\right.$ of soil). The application of bioconsolidation can lead to a tenfold change in the primary properties of the sand such as permeability, stiffness, compressibility and shear strength (DeJong et al. 2010). MICP treatment has contributed greatly to improvement of the engineering properties of residual soil, but its applicability to soil types other than sand is still very limited (Soon et al. 2014). In addition, MICP improved the durability of construction and cementation materials.

The chemical grouting technique is not only expensive, but also requires many injection wells for treatment of large volumes. Using MICP, the reagents and catalysts are injected and transported to the location at which strengthening is required (Dhami et al. 2013a). Many researchers have reported improvement of shear strength and reduction in permeability of soil in response to ureolytic bacteria (DeJong et al. 2006; Whiffin et al. 2007; Chu et al. 2012). The $\mathrm{CO}_{3}{ }^{2-}$ ions precipitate with $\mathrm{Ca}^{2+}$ as calcite crystal, which generates cementing bridges between sand particles (Figs. 1,3). The plugging of the soil restricts the water flow through the soil and then reduces the permeability. The calcite crystals formed between the soils particles along with embedded bacteria suggest that bacteria served as nucleation sites during the mineralization process (Stocks-Fischer et al. 1999; Ng et al. 2012). An increase of pores plugged due to the reaction of calcite was observed in the presence of vegetative cells and spores of Lysinibacillus sphaericus WJ-8 of soil (Fig. 6. Unpublished data).

\section{Bioconcrete or biocementation}

Cement is widely used as a construction material to strengthen soil (Stabnikov et al. 2013). However, the production of cement has environment impacts during all stages of manufacturing. Additionally, global cement production accounts for about $5 \%$ of the total industrial energy consumption and $5 \%$ of anthropogenic $\mathrm{CO}_{2}$ emissions (Worrel et al. 2001). Chemical grout, which can be used in place of cement to strengthen soil, employs sodium silicate, calcium chloride, calcium hydroxide, acrylates, and acrylamides to bind soil particles (Karol 2003; Ivanov and Chu 2008). However, this method is expensive and toxic to humans and the environment (Karol 2003; DeJong et al. 2006; Ivanov and Chu 2008). Therefore, economical alternatives to chemical grouting are necessary. Biocement is an alternative to cement and chemical grouts (De Muynck et al. 2010; Stabnikov et al. 2011) that can produce binder materials via MICP treatment to seal fractures and improve the strength and durability of cementious materials (Phillips et al. 2013; Dhami et al. 2014). Biocementation of MICP has been applied to strengthen soil and treat the cracks in concrete (Ramachandran et al. 2001; De Muynck et al. 2008). Soil cementation materials include carbonates, hydroxides, phosphates, silicates and sulfides 

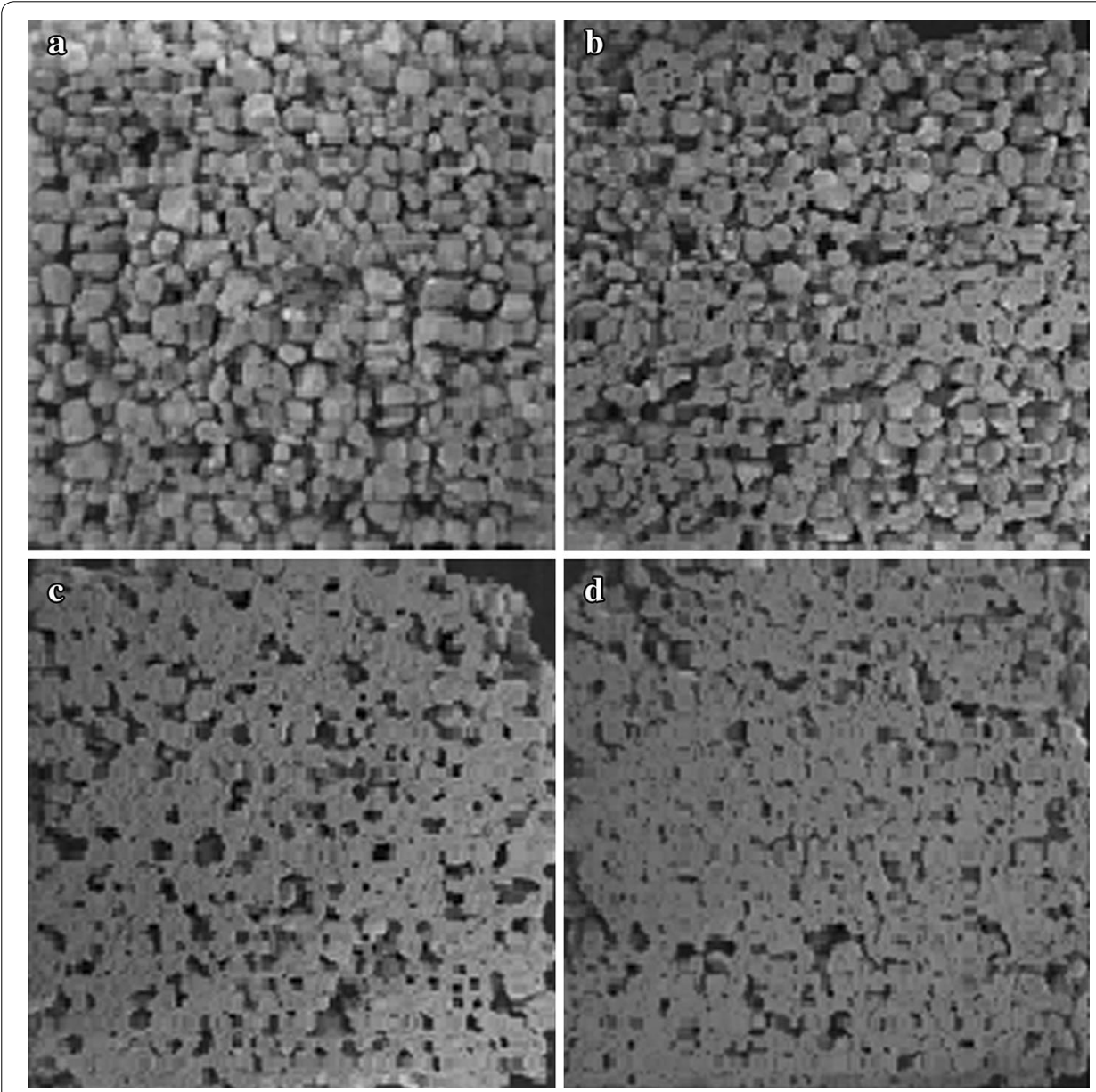

Fig. 6 Scanning electron micrograph showing the bioconsolidated soil from L. sphaericus WJ-8. a Water, b YAU media, c vegetative cell only, d vegetative cell and spore. (Unpublished data)

(Ivanov and Chu 2008). Calcium carbonate is primarily used in biocementation because it is commonly found in nature. Biocement can improve soil shear strength through the production of soil particle-binding materials in response to the introduction of bacteria and cementation reagents into the soil (Ng et al. 2012). Different bacterial strains have been shown to produce various levels of urease activity ranging from 2.2 to $20 \mathrm{mM}$ of hydrolyzed urea/min (Harkes et al. 2010; Stabnikov et al. 2013). Urease activity should not be too high or too low for successful biocementation because urease activity in the range of 4.4 to $9.5 \mathrm{mM}$ hydrolyzed urea/min. increased the strength of biocemented soil. Qian et al. (2009) reported that stronger aggregates of calcium carbonate formed at a low rate of urea hydrolysis. Following MICP treatment (by BHI cured bricks), the absorption of water by bricks cured in the media was lower $(-14 \%)$ than that of the control (25\%) because pores were blocked by calcite deposition, which prevented water and other pollutants from penetrating into the body of the bricks (Sarada et al. 2009). Ramachandran (2007) found that incorporation of high concentrations of bacterial cells into the cement mixture reduced compressive strength owing to inference of the biomass with the integrity of the mortar. However, other researchers reported that the compressive strength 
improved after MICP treatment relative to a control (De Muynck et al. 2008; Chahal et al. 2012).

The cracks form in concrete due to aging and freeze thaw cycles; however, many researchers have reported the remediation of cracks by MICP of B. pasteurii and other Bacillus species (Ramachandran et al. 2001; Achal et al. 2013). Bioclogging of soil restricts water flow through soil and reduces its permeability. The permeability of soil was reduced significantly through accumulation of biomass and production of exopolymeric substances (Vandevivere and Baveye 1992; Ng et al. 2012). DeJong et al. (2010) reported a reduction of pore size, porosity, and permeability, as well as improvement of the stiffness and strength of the porous media matrix in response to MICP. Bernardi et al. (2014) recently reported the manufacture of bio-bricks by MICP and compared the effectiveness with that of conventional cement and lime treated bricks. Actually, the type of $\mathrm{CaCO}_{3}$ polymorphs is important to the construction purpose because it has high stability and consolidating effects (Rodriguez-Navarro et al. 2003; Ganendra et al. 2014). The growth of B. pasteurii is affected by very high $\mathrm{pH}$ (above 12), particularly in concrete, because the optimum $\mathrm{pH}$ for the best growth of this strain is 9.0. For this instance, Bang et al. (2001) investigated an immobilization technique utilizing polyurethane (PU) for remediation of concrete cracks to protect the bacterial cells from the high $\mathrm{pH}$ of the concrete. However, during whole cell immobilization in PU, the viability of the cells encapsulated in PU polymer is uncertain (Wang and Ruchenstein 1993; Bang et al. 2001). Nevertheless, Bachmeier et al. (2002) suggested that the immobilized enzyme could overcome the loss of viability of whole cells in PU and that the immobilized enzyme will be environmentally safer than immobilized microorganisms. MICP is also involved in protection of concrete surfaces against the ingress of deleterious substances (e.g., chloride ions) (De Muynck et al. 2008).

\section{$\mathrm{CO}_{2}$ sequestration}

Global warming is a major environmental issue occurring primarily in response to increasing concentrations of $\mathrm{CO}_{2}$ in the earth's atmosphere (Yadav et al. 2011). Currently, the concentration of $\mathrm{CO}_{2}$ in the earth's atmosphere is about $400 \mathrm{ppm}$; however, this is increasing at approximately $2 \mathrm{ppm}$ /year (Source from Wikipidia). Thus, there is an urgent need to reduce the release of $\mathrm{CO}_{2}$ into the environment. The increasing atmospheric $\mathrm{CO}_{2}$ levels are mainly due to the burning of fossil fuels for energy production and consumption and other activities such as cement production and tropical deforestation (Malhi and Grace 2000; Goel 2010). $\mathrm{CO}_{2}$ is primarily removed from the atmosphere via photosynthesis by plants and marine organisms, while it is returned to the atmosphere via respiration by animals and chemoorganotrophic organisms. Many investigators have used different mechanisms to capture and dispose of $\mathrm{CO}_{2}$ in an environmentally safe manner (Sharma and Bhattacharya 2010). The most effective way to lower $\mathrm{CO}_{2}$ emissions into the environment is to reduce fossil fuel consumption. In nature, $\mathrm{CO}_{2}$ is sequestered by chemical fixation of $\mathrm{CO}_{2}$ in the form of carbonate such as calcite, aragonite, magnesite and dolomite, but the reaction rate is very slow (Mann 2001; Dhami et al. 2013a). Many researchers have proposed an alternative method of biological sequestration of $\mathrm{CO}_{2}$ by carbonic anhydrase (CA) enzyme to reduce atmospheric $\mathrm{CO}_{2}$ (Ramanan et al. 2009; Yadav et al. 2011). CA is a zinc containing metallo-enzyme that catalyzes the 
reverse hydration of $\mathrm{CO}_{2}$ to bicarbonate and is ubiquitous in prokaryotes and eukaryotes. In eukaryotes, $\mathrm{CA}$ is involved in many biochemical and physiological process such as photosynthesis, respiration, $\mathrm{CO}_{2}$ and ion transport and acid base balance (Karlsson et al. 1998; Tripp et al. 2001; Zhang et al. 2011; Dhami et al. 2014).

MICP is an effective method for the removal of $\mathrm{CO}_{2}$ from the environment (Ferris et al. 1994; Mitchell et al. 2010). In this method, $\mathrm{CO}_{2}$ is converted into carbonate minerals that can form different crystals such as calcite, aragonite, dolomite and magnesite. This method is safer and more eco-friendly than conventional methods of sequestering $\mathrm{CO}_{2}$ from the atmosphere. Bond et al. (2001) reported positively the transformation of $\mathrm{CO}_{2}$ to bicarbonate in the presence of $\mathrm{Ca}^{2+}$ in artificial sea water and a rapid decrease in $\mathrm{CO}_{2}$ concentration and increase in $\mathrm{CaCO}_{3}$ synthesis with CA enzyme. Liu et al. (2005) and Kim et al. (2012) found that the bovine CA and recombinant CA from Nisseria gonorrhoeae (NCA), rapidly catalyzed the reversible hydration of $\mathrm{CO}_{2}$ to bicarbonate and calcite crystal formations. Several studies confirmed that $\mathrm{CO}_{2}$ could be effectively sequestered into carbonate by CA from different organisms (Bond et al. 2001; Ramanan et al. 2009). Ramanan et al. (2009) investigated whether the addition of CA enzyme to reaction mixtures containing $\mathrm{CaCl}_{2}$ solution saturated with $\mathrm{CO}_{2}$, resulted in enhanced deposition of carbonate/bicarbonate salts. They also compared carbonate deposition by crude enzyme with purified enzyme. The purified enzyme was able to deposit almost 15 times more carbonate than crude enzyme (Ramanan et al. 2009). Most sequestration studies conducted to date have been based on the assumption that $\mathrm{CO}_{2}$ must first be separated from the exhaust gas produced by fossil-fuel combustion and then disposed of in depleted oil and gas wells, deep saline aquifers in the ocean or through deposition into minerals (Dupraz et al. 2009). Using this approach, CA enzymes are able to capture and fix anthropogenic $\mathrm{CO}_{2}$ into solid carbonate $\left(\mathrm{CaCO}_{3}\right)$, resulting in production of a stable eco-friendly benign product (Ramanan et al. 2009).

The geological sequestration of $\mathrm{CO}_{2}$ has also been accomplished by the injection of supercritical $\mathrm{CO}_{2}\left(\mathrm{SC}-\mathrm{CO}_{2}\right)$ into deep geological environments, oil bearing formations, deep-seated coal beds and deep saline aquifers (White et al. 2003; Haszeldine et al. 2005; Mitchell et al. 2010). The critical over-saturation values necessary for $\mathrm{CaCO}_{3}$ precipitation have been discussed by many researchers (Ferris et al. 2003; Dupraz et al. 2009). These environments are known to shelter extensive and active microbial communities that could possibly interact with the injected $\mathrm{CO}_{2}$ (Amend and Teske 2005; Dupraz et al. 2009) (Fig. 7). Among many carbon capture and storage technologies, biotechnology using CA in an immobilized enzyme reactor at these plants holds great promise because it is viable and environmentally benign (Liu et al. 2005), and the generated carbonate minerals are safe methods of long term $\mathrm{CO}_{2}$ storage.

\section{Other applications}

The preparation of useful products based on the integration of $\mathrm{CO}_{2}$ fixation and biomass utilization is important to future development of environmental engineering strategies. In material engineering, environmentally friendly technologies are required for the production of materials and composite with minimum levels of energy consumption, resource depletion and despoilment (Wakayama et al. 2005). The MICP method is an alternative method for the production of several materials. The biominerals of calcium 


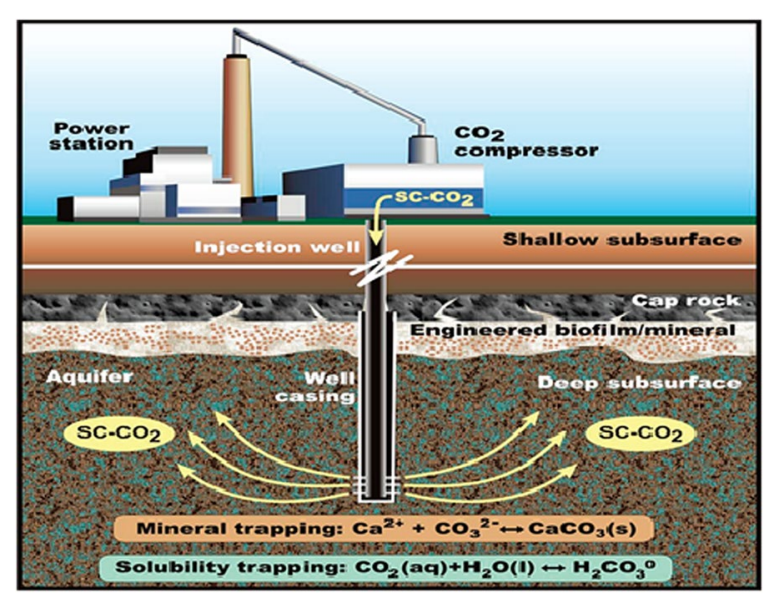

Fig. 7 Schematic diagram of microbially enhanced carbon capture and storage (Source from Mitchell et al. 2010)

carbonate or calcium phosphate are involved in production of complex multifunctional composites with organic macromolecules at extreme temperature and pressure (Wakayama et al. 2005). Particularly, calcite formed by Geobacillus thermoglucosidasius has many advantages when applied as filler in rubber and plastics, fluorescent particles in stationary ink and stationary markers for western blotting and other biochemistry applications (Ling et al. 2009; Yoshida et al. 2010).

Polychlorinated biphenyls (PCBs) containing oils comprise a serious environmental concern with the potential to impact human health. There are several methods available for removal of PCBs contaminated oil from the environment including solvent washing and hydroblasting followed by encapsulation in epoxy coatings, but these methods are ineffective for the removal of PCBs successfully. Alternatively, MICP is able to produce a coating to seal PCBs-contaminated areas. Indeed, MICP coated areas showed no leaching and a reduction in permeability of $1-5$ orders or magnitude (Okwadha and Li 2011).

High concentrations of calcium ions in industrial wastewater are problematic because of the clogging of pipelines, boilers and heat exchangers through scaling or malfunctioning of aerobic and anaerobic reactors (Yu et al. 2001; Hammes et al. 2003b). MICP is an alternative technology for removal of inorganic contaminants from the environment, and many researchers have reported the use of MICP methods for removal of calcium from industrial wastewater (Van Langerak et al. 1997; Hammes et al. 2003a, b). Van Langerak et al. (1997) reported the removal of calcium from industrial wastewater using a fluidized sand bed calcification reactor that employed the alkalinity generated by microbes in a standard up-flow anaerobic sludge bed reactor. Using the biocatalytic calcification reactor, approximately $85-90 \%(w / v)$ of the soluble calcium was precipitated as calcium carbonate and successfully removed through sedimentation in the treatment reactor (Hammes et al. 2003b). Therefore, this is an effective, eco-friendly and simple method for removal of calcium from industrial wastewater. 


\section{Limitations and perspectives regarding MICP}

Most potential applications of MICP technology in various fields have been discussed. However, there are a few limitations to the use of MICP that must be overcome before it can be widely applied on a commercial scale.

1. MICP may not be completely environmental friendly, because ammonium and nitrate are formed during the ureolysis-driven process, which can be toxic and hazardous to human health and soil microorganisms at high concentrations (Van Paassen et al. 2010). Additionally, ammonium present inside building materials can be nitrified into nitric acid by bacteria. This can in turn react with calcite to form calcium nitrate, which is a highly soluble component that contributes to bio-deterioration of building materials (Ganendra et al. 2014). Ganendra et al. (2014) recently investigated the MICP process (i.e., formate oxidation-driven $\mathrm{CaCO}_{3}$ precipitation) using calcium formate produced by Methylocystis parvus OBBP. They found that it was advantageous over ureolysis-driven processes because the calcium formate did not release the ammonia to the air or produce nitric acid when applied to building materials, resulting in decreased risk of pollution and bio-deterioration of the materials.

2. Another disadvantage of MICP is that microbial processes are usually slower and more complex than chemical process. This is because microbial activity is completely dependent on environmental factors such as temperature, $\mathrm{pH}$, concentration of donors and acceptors of electrons, and concentration and diffusion rates of nutrients and metabolites. (Ivanov and Chu 2008). Therefore, it is difficult to apply MICP on a commercial scale.

3. The economic limitations to use of laboratory grade nutrient sources in field applications must be overcome. To address this, identification of alternative inexpensive nutrient sources for MICP technology is necessary. For example, corn steep liquor or lactose mother liquor may provide less expensive nutrient sources for successful commercialization (Achal et al. 2009b; Mitchell et al. 2010; Dhami et al. 2013a; Phillips et al. 2013). In addition to this limitation, the production of large volumes of reactants and bacterial cultures make MICP economically challenging when compared to traditional methods. Finally, additional investigations to improve the technology and reduce unwanted byproducts are needed to enable use of MICP on a commercial scale.

\section{Conclusions}

A wide variety of microorganisms can be used in the production of urease for ureolysisdriven processes. However, microorganisms such as Sporosarcina pasteurii and B. megaterium have the greatest potential for use in MICP. Many researchers have developed various conventional methods for environmental clean-up, but these methods are inefficient and expensive. MICP has emerged as an effective and ecofriendly method for environmental remediation. MICP is used in various fields to remediate heavy metals and radionuclides from contaminated environments and for sequestration of atmospheric $\mathrm{CO}_{2}$. In addition, the same technology can be used to improve soil and sand quality, as well as cement sealing of concrete. MICP applications are not limited and are useful to 
other applications to produce safe and environmentally stable products. Even though the MICP process has many merits, further study is needed to overcome the limitations to use of this technology prior to its commercialization.

\section{Authors' contributions}

PA participated in the design and contribution of the experiments and written of the review article. CHK contributed in heavy metal and radionuclide sequestration experiments and helped to draft the manuscript. YJS participated in MICP studies and draft the manuscript. JSS contributed in design the experiment and discussed many critical points. All authors read and approved the final manuscript.

\section{Acknowledgements}

This research was supported by Basic Science Research Program through the National Research Foundation of Korea (NRF) funded by the Ministry of Education (NRF-2015R1D1A1A01056788) and in part by an Inha University Research Grant.

\section{Competing interests}

The authors declare that they have no competing interests.

Received: 21 October 2015 Accepted: 16 February 2016

Published online: 01 March 2016

\section{References}

AbdEl-Sabour MF (2007) Remediation and bioremediation of uranium contaminated soils. Electron J Environ Agr Food Chem 6:2009-2023

Achal V, Pan X (2014) Influence of calcium sources on microbially induced calcium carbonate precipitation by Bacillus sp. CR2. Appl Biochem Biotechnol 173:307-317

Achal V, Mukherjee A, Basu PC, Reddy MS (2009a) Strain improvement of Sporosarcina pasteurii for enhanced urease and calcite production. J Ind Microbiol Biotechnol 36:981-988

Achal V, Mukherjee A, Basu PC, Reddy MS (2009b) Lactose mother liquor as an alternative nutrient source for microbial concrete production by Sporosarcina pasteurii. J Ind Microbiol Biotechnol 36:433-438

Achal V, Pan X, Zhang D (2011) Remediation of copper-contaminated soil by Kocuria flava CR1 based on microbially induced calcite precipitation. Ecol Eng 37:1601-1605

Achal V, Pan X, Zhang D, Fu Q (2012a) Bioremediation of Pb-contaminated soil based on microbially induced calcite precipitation. J Microbiol Biotechnol 22:244-247

Achal V, Pan X, Fu Q, Zhang D (2012b) Biomineralization based remediation of As(III) contaminated soil by Sporosarcina ginsengisoli. J Hazard Mater 201-202:178-184

Achal V, Pan X, Zhang D (2012c) Bioremdiation of strontium (Sr) contaminated aquifer quartz sand based on carbonate precipitation induced by Sr resistant Halomonas sp. Chemosphere 89:764-768

Achal V, Pan X, Lee DJ, Kumari D, Zhang D (2013) Remediation of Cr(VI) from chromium slag by biocementation. Chemosphere 93:1352-1358

Ahmadpour A, Zabihi M, Tahmasbi M, Bastami TR (2010) Effect of adsorbents and chemical treatments on the removal of strontium from aqueous solutions. J Hazard Mater 182:552-556

Aksornchu P, Prasertsan P, Sobhon V (2008) Isolation of arsenic-tolerant bacteria from arsenic-contaminated soil. Songklanakarin J Sci Technol 30:95-102

Amend JP, Teske A (2005) Expanding frontiers in deep subsurface microbiology. Paleogeogr Paleoclimatol Paleoecol 219:131-155

Arias JL, Fernandez MS (2008) Polysaccharides and proteoglycans in calcium carbonate-based biomineralization. Chem Rev 108:4475-4482

Bachmeier KL, Williams AE, Warmington JR, Bang SS (2002) Urease activity in microbiologically-induced calcite precipitation. J Biotechnol 93:171-181

Bahadir T, Bakan G, Altas L, Buykgungar H (2007) The investigation of lead removal by biosorption. An application at storage battery industry wastewaters. Enz Microbiol Technol 41:98-102

Bai HJ, Zhang ZM, Yang GE, Li BZ (2008) Bioremediation of cadmium by growing Rhodobacter sphaeroides: kinetic characteristic and mechanism studies. Bioresour Technol 99:7716-7722

Bang SS, Galinat JK, Ramakrishnan V (2001) Calcite precipitation induced by polyurethane-immobilized Bacillus pasteurii. Enz Microb Technol 28:404-409

Barkay T, Schaefer J (2001) Metal and radionuclide bioremediation: issues, considerations and potentials. Curr Opin Microbiol 4:318-323

Basha EA, Hashim R, Mahmud HB, Muntohar AS (2005) Stabilization of residual soil with rice husk ash and cement. Constr Build Mater 19:448-453

Ben Chekroun K, Rodriguez-Navarro C, Gonzalez-Munoz MT, Arias JM, Cultrone G, Rodriguez-Gallego M (2004) Precipitation and growth morphology of calcium carbonate induced by Myxococcus xanthus: implications for recognition of bacterial carbonates. J Sediment Res 74:868-876

Benzerara K, Miot J, Morin G, Ona-Nguema G, Skouri-Panet F, Ferard C (2011) Significance, mechanisms and environmental implications of microbial biomineralization. CR Geosci 343:160-167 
Bernardi D, DeJong JT, Montoya BM, Martinez BC (2014) Bio-bricks: biologically cemented sandstone bricks. Constr Build Mater 55:462-469

Bond GM, Stringer J, Brandvold DK, Simsek FA, Medina MG, Egeland G (2001) Development of integrated system for biomimetic $\mathrm{CO}_{2}$ sequestration using the enzyme carbonic anhydrase. Energy Fuels 15:309-316

Bosak T (2011) Calcite precipitation, microbially induced. In: Reitner J, Thiel V (eds) Encyclopedia of earth sciences series. Springer, Netherlands, pp 223-227

Brookshaw D, Pattrick R, Lloyd J, Vaughan D (2012) Microbial effects on mineral-radionuclide interactions and radionuclide solid-phase capture processes. Mineral Mag 76:777-806

Burbank MB, Weaver TJ, Williams BC, Crawford RL (2012) Urease activity of ureolytic bacteria isolated from six soils in which calcite was precipitated by indigenous bacteria. Geomicrobiol J 29:389-395

Burne RA, Chen YY (2000) Bacterial ureases in infectious diseases. Microbes Infect 2:533-542

Castanier S, Le Metayer-Levrel G, Perthuisot JP (1999) Ca-carbonates precipitation and limestone genesis-the microbiogeologist point of view. Sediment Geol 126:9-23

Chahal N, Siddique R, Rajor A (2012) Influence of bacteria on the compressive strength, water absorption and rapid chloride permeability of fly ash concrete. Construct Build Mater 28:351-356

Chandra P, Sinha S, Rai UN (1997) Phytoremediation of soil and water contaminants. In: Anderson TA, Coats JR (eds) Kruger EL, vol 664., Phytoremediation of soil and water contaminantsAmerican Chemical Society, Washington (DC), pp 274-282

Chen L, Shen Y, Xie A, Huang B, Jia R, Guo R, Tang W (2009) Bacteria-mediated synthesis of metal carbonate minerals with unusual morphologies and structures. Crys Growth Des 9:743-754

Chu J, Stabnikov V, Ivanov V (2012) Microbially induced calcium carbonate precipitation on surface or in the bulk of soil. Geomicrobiol J 29:544-549

Cuthbert MO, Riley MS, Handley-Sidhu S, Renshaw JC, Tobler DJ, Phoenix VR, Mackay R (2012) Controls on the rate of ureolysis and the morphology of carbonate precipitated by S. pasteurii biofilms and limits due to bacterial encapsulation. Ecol Eng 41:32-40

De Muynck W, Cox K, De Belie N, Verstraete W (2008) Bacterial carbonate precipitation as an alternative surface treatment for concrete. Constr Build Mater 22:875-885

De Muynck W, De Belie N, Verstraete W (2010) Microbial carbonate precipitation in construction materials: a review. Ecol Eng 36:118-136

De Yoreo JJ, Vekilov PG (2003) Principles of crystal nucleation and growth. Rev Mineral Geochem 54:57-93

Dejong JT, Fritzges MB, Nusslein K (2006) Microbial induced cementation to control sand response to undrained shear. J Geotech Geoenviron Eng 132:1381-1392

DeJong JT, Mortensen BM, Martinez BC, Nelson DC (2010) Bio-mediated soil improvement. Ecol Eng 36:197-210

Dhami NK, Reddy MS, Mukherjee A (2013a) Bimineralization of calcium carbonates and their engineered applications: a review. Front Microbiol 4:1-13

Dhami NK, Reddy MS, Mukherjee A (2013b) Biomineralization of calcium carbonate polymorphs by the bacterial strains isolated from calcareous sites. J Microbiol Biotechnol 23:707-714

Dhami NK, Reddy MS, Mukherjee A (2014) Synergistic role of bacterial urease and carbonic anhydrase in carbonate mineralization. Appl Biochem Biotechnol 172:2552-2561

Di Maio VJM (2001) Forensic pathology, 2nd edn. CRC Press, Boca Raton, p 527

Douglas S, Beveridge TJ (1998) Mineral formation by bacteria in natural microbial communities. FEMS Microbiol Ecol 26:79-88

Dupraz S, Menez B, Gouze P, Leprovost R, Benezeth P, Pokrovsky OS, Guyot F (2009) Experimental approach of $\mathrm{CO}_{2}$ biomineralization in deep saline aquifers. Chem Geol 265:54-62

El-Kamash AM, El-Naggar MR, El-Dessouky MI (2006) Immobilization of cesium and strontium radionuclides in zeolitecement blends. J Hazard Mater B136:310-316

Favre N, Christ ML, Pierre AC (2009) Biocatalytic capture of $\mathrm{CO}_{2}$ with carbonic anhydrase and its transformation to solid carbonate. J Mol Catal B Enzym 60:163-170

Fayiga AO, Ma LQ, Cao X, Rathinasabapathi B (2004) Effects of heavy metals on growth and arsenic accumulation in the arsenic hyperaccumulator Pteris vittata L. Environ Pollut 132:289-296

Ferrer MR, Quevedo-Sarmiento J, Bejar V, Delgado R, Ramos-Cormenzana A, Rivadeneyra MA (1988) Calcium carbonate formation by Deleya halophila: effect on salt concentration and incubation temperature. Geomicrobiol J 6:49-57

Ferris FG, Wiese RG, Fyfe WS (1994) Precipitation of carbonate minerals by microorganisms: implications for silicate weathering and the global carbon dioxide budget. Geomicrobiol J 12:1-13

Ferris FG, Stehmeier LG, Kantzas A, Mourits FM (1996) Bacteriogenic mineral plugging. J Can Petr Technol 35:56-61

Ferris FG, Phoenix V, Fujita Y, Smith RW (2003) Kinetics of calcite precipitation induced by ureolytic bacteria at 10 to $20^{\circ} \mathrm{C}$ in artificial groundwater. Geochim Cosmochim Acta 67:1701-1710

Fu F, Wang Q (2011) Removal of heavy metal ions from wastewaters: a review. J Environ Manage 92:407-418

Fujita Y, Redden GD, Ingram JC, Cortez MM, Ferris FG, Smith RW (2004) Strontium incorporation into calcite generated by bacterial ureolysis. Geochim Cosmochim Acta 68:3261-3270

Fujita Y, Taylor JL, Gresham T, Delwiche M, Colwell F, McLing T, Petzke L, Smith R (2008) Stimulation of microbial urea hydrolysis in groundwater to enhance calcite precipitation. Environ Sci Technol 42:3025-3032

Fujita Y, Taylor J, Wendt L, Reed D, Smith R (2010) Evaluating the potential of native ureolytic microbes to remediate ${ }^{90} \mathrm{Sr}$ contaminated environment. Environ Sci Technol 44:7652-7658

Gadd GM (2000) Bioremedial potential of microbial mechanisms of metal mobilization and immobilization. Curr Opin Biotechnol 11:271-279

Ganendra G, De Muynck W, Ho A, Arvaniti EC, Hosseinkhani B, Ramos JA, Rahier H, Boon N (2014) Formate oxidationdriven calcium carbonate precipitation by Methylocystis parvus OBBP. Appl Environ Microbiol 80:4659-4667

Gazso LG (2001) The key microbial processes in the removal of toxic metals and radionuclides from the environment. CEJOEM 7:178-185 
Gebauer D, Gunawidjaja PN, Peter Ko JY, Bacsik Z, Aziz B, Liu L, Hu Y, Bergstrom L, Tai CW, Sham TK, Eden M, Hedin N (2010) Proto-calcite and proto-vaterite in amorphous calcium carbonates. Angew Chem Int Ed 49:8889-8891

Goel M (2010) Carbon capture and storage: science and technology focus for mitigation of climate change. Int Assoc Energy Econ 19:37-40

Gonzalez-Munoz MT, Rodriguez-Navarro C, Martinez-Ruiz F, Arias JM, Merroun ML, Rodriguez-Gallego M (2010) Bacterial biomineralization: new insights from Myxococcus - induced mineral precipitation. Geol Soc Lond Sp Pub 336:31-50

Gorospe CM, Han SH, Kim SG, Park JY, Kang CH, Jeong JH, So JS (2013) Effects of different calcium salts on calcium carbonate crystal formation by Sporosarcina pasteurii KCTC 3558. Biotechnol Bioproc Eng 18:903-908

Guo H, Luo S, Chen L, Xiao X, Xi Q, Wei W, Zeng G, Liu C, Wan Y, Chen J, He Y (2010) Bioremediation of heavy metals by growing hyperaccumulator endophytic bacterium Bacillus sp. L14. Bioresour Technol 101:8599-8605

Hamdan N, Kavazanjian E, Rittmann BE (2011) Sequestration of radionuclides and metal contaminants through microbially-induced carbonate precipitation. Pan-Am CGS Geotechnical conference, Toronto

Hammes F, Verstraete W (2002) Key roles of pH and calcium metabolism in microbial carbonate precipitation. Rev Environ Sci Biotechnol 1:3-7

Hammes F, Boon N, de Villiers J, Verstraete W, Siciliano SD (2003a) Strain-specific ureolytic microbial calcium carbonate precipitation. Appl Environ Microbiol 69:4901-4909

Hammes F, Seka A, Hege KV, de Wiele TV, Vanderdeelen J, Siciliano SD, Verstraete W (2003b) Calcium removal from industrial wastewater by bio-catalytic $\mathrm{CaCO}_{3}$ precipitation. J Chem Technol Biotechnol 78:670-677

Harkes MP, van Paassen LA, Booster JL, Whiffin VS, van Loosdrecht MCM (2010) Fixation and distribution of bacterial activity in sand to induce carbonate precipitation for ground reinforcement. Ecol Eng 36:112-117

Haszeldine RS, Quinn O, England G, Wilkinson M, Shipton ZK, Evans JP, Heath J, Crossey L, Ballentine CJ, Graham CM (2005) Natural geochemical analogues for carbon dioxide storage in deep geological porous reservoirs, a United Kingdom perspective. Oil Gas Sci Technol 60:33-49

Hesse A, Heimbach D (1999) Causes of phosphate stone formation and the importance of metaphylaxis by urinary acidification: a review. World J Urol 17:308-315

Hua B, Deng B, Thornton EC, Yang J, Amonette JE (2007) Incorporation of chromate into calcium carbonate structure during coprecipitation. Water Air Soil Pollut 179:381-390

Huat BBK (2006) Deformation and shear strength characteristics of some tropical peat and organic soils. Pertanika J Sci Technol 14:61-74

Ivanov V, Chu J (2008) Applications of microorganisms to geotechnical engineering for bioclogging and biocementation of soil in situ. Rev Environ Sci Biotechnol 7:139-153

Jeyasingh J, Philip L (2005) Bioremediation of chromium contaminated soil: optimization of operating parameters under laboratory conditions. J Hazard Mater 118:113-120

Kamaludeen SP, Megharaj M, Juhasz AL, Sethunathan N, Naidu R (2003) Chromium-microorganism interactions in soils: remediation implications. Rev Environ Contam Toxicol 178:93-164

Kang CH, Han SH, Shin YJ, Oh SJ, So JS (2014a) Bioremediation of Cd by microbially induced calcite precipitation. Appl Biochem Biotechnol 172:1929-1937

Kang CH, Choi JH, Noh JG, Kwak DY, Han SH, So JS (2014b) Microbially induced calcite precipitation-based sequestration of strontium by Sporosarcina pasteurii WJ-2. Appl Biochem Biotechnol 174:2482-2491

Kang CH, Oh SJ, Shin YJ, Han SH, Nam IH, So JS (2015a) Bioremediation of lead by ureolytic bacteria isolated from soil at abandoned metal mines in South Korea. Ecol Eng 74:402-407

Kang CH, Kwon YJ, So JS (2015b) Soil bioconsolidation through microbially induced calcite precipitation by Lysinibacillus sphaericus WJ-8. Geomicrobiol J. doi:10.1080/01490451.2015.1053581

Kapoor A, Viraraghavan T (1995) Fungal biosorption —an alternative treatment option for heavy metal bearing wastewaters: a review. Bioresour Technol 53:195-206

Karatas I, Kavazanjian JE, Rittmann BE (2008) Microbially induced precipitation of calcite using Pseudomonas denitrificans. In: Proceedings of 1st bio-geo engineering conference, TU Delft and Deltares, Delft, The Netherlands. pp. 58-66

Karlsson J, Clarke AK, Chen ZY, Hugghins SY, Park YI, Husic HD, Moroney JV, Samuelsson G (1998) A novel a-type carbonic anhydrase associated with the thylakoid membrane in Chlamydomonas reinhardtii required for growth at ambient $\mathrm{CO}_{2}$. EMBO J 17:1208-1216

Karol RH (2003) Chemical grouting and soil stabilization. Marcel Dekker, New York (NY), p 558

Kawaguchi T, Decho AW (2002) A laboratory investigation of cyanobacterial extracellular polymeric secretion (EPS) in influencing $\mathrm{CaCO}_{3}$ polymorphism. J Cryst Growth 240:230-235

Khodadadi T, Bilsel H (2012) Application of microorganisms for improvement of liquefiable sand. In: 3rd international conference on new development in soil mechanics and geotechnical engineering. Near East University, Nicosia, North Cyprus, pp 857-863

Kim IG, Jo BH, Kang DG, Kim CS, Choi YS, Cha HJ (2012) Biomineralization-based conversion of carbon dioxide to calcium carbonate using recombinant carbonic anhydrase. Chemosphere 87:1091-1096

Kirk MF, Holm TR, Park J, Jin Q, Sanford RA, Fouke BW, Bethke CM (2004) Bacterial sulfate reduction limits natural arsenic contamination in groundwater. Geology 32:953-956

Konishi Y, Tsukiyama T, Ohno K, Saitoh N, Nomura T, Nagamine S (2006) Intracellular recovery of gold by microbial reduction of $\mathrm{AuCl}_{4}{ }^{-}$ions using the anaerobic bacterium Shewanella algae. Hydrometallurgy 81:24-29

Krumbein WE (1979) Photolithotrophic and chemoorganotrophic activity of bacteria and algae as related to beach rock formation and degradation (Gulf of Agaba, Sinai). Geomicrobiol J 1:139-203

Lauchnor EG, Schultz LN, Bugni S, Mitchell AC, Cunningham AB, Gerlach R (2013) Bacterially induced calcium carbonate precipitation and strontium coprecipitation in a porous media flow system. Environ Sci Technol 47:1557-1564

Li M, Cheng X, Guo H (2013) Heavy metal removal by biomineralization of urease producing bacteria isolated from soil. Int Biodeter Biodegr 76:81-85

Lin CC, Lin HL (2005) Remediation of soil contaminated with the heavy metal $\left(\mathrm{Cd}^{2+}\right)$. J Hazard Mater 122:7-15 
Ling H, Mao Z, Gao C (2009) Fabrication of fluorescent microparticles by doping water-soluble CdTe nanoparticles into calcium carbonate for monitoring intracellular uptake. Colloids Surf A Physicochem Eng Asp 336:115-122

Liu N, Bond GM, Abel A, McPherson BJ, Stringer J (2005) Biomimetic sequestration of $\mathrm{CO}_{2}$ in carbonate form: role of produced waters and other brines. Fuel Process Technol 86:1615-1625

Lloyd JR, Lovely DR (2001) Microbial detoxification of metals and radionuclides. Curr Opin Biotechnol 12:248-253

Loewenthal RE, Marais GVR (1978) Carbonate chemistry of aquatic systems: theory and application, vol 1. Ann Arbor Science, Ann Arbor

Lowenstam HA (1981) Minerals formed by organisms. Science 211:1126-1131

Lowenstam HA, Weiner S (1989) On biomineralization. Oxford University Press, New York

Lytle CM, Lytle FW, Yang N, Qian JH, Hansen D, Zayed A, Terry N (1998) Reduction of Cr(VI) to Cr(III) by wetland plants: potential for in situ heavy metal detoxification. Environ Sci Technol 32:3087-3093

Ma Y, Lin C, Jiang Y, Lu W, Si C, Liu Y (2009) Competitive removal of water-borne copper, zinc and cadmium by a $\mathrm{CaCO}_{3}{ }^{-}$ dominated red mud.J Hazard Mater 172:1288-1296

Malhi Y, Grace J (2000) Tropical forests and atmospheric carbon dioxide. Trends Ecol Evol 15:332-337

Mann S (2001) Biomineralization: principle and concepts in bioinorganic materials chemistry. Oxford University Press, New York

McConnaughey TA, Whelan FF (1997) Calcification generates protons for nutrient and bicarbonate uptake. Earth Sci Rev 42:95-117

Mishra SP, Tiwary D (1999) Ion exchangers in radioactive waste management: Part XI. Removal of barium and strontium ions from aqueous solutions by hydrous ferric oxide. Appl Radiat Isot 51:359-366

Mitchell AC, Ferris FG (2005) The coprecipitation of Sr into calcite precipitates induced by bacterial ureolysis in artificial groundwater: temperature and kinetics dependence. Geochim Gosmochim Acta 69:4199-4210

Mitchell AC, Ferris FG (2006) Effect of strontium contaminants upon the size and solubility of calcite crystals precipitated by the bacterial hydrolysis of urea. Environ Sci Technol 40:1008-1014

Mitchell AC, Dideriksen K, Spangler LH, Cunningham AB, Gerlach R (2010) Microbially enhanced carbon capture and storage by mineral-trapping and solubility-trapping. Environ Sci Technol 44:5270-5276

Mobley HLT, Hausinger RP (1989) Microbial urease: significance, regulation and molecular characterization. Microbiol Rev 53:85-108

Mobley HLT, Island MD, Hausinger RP (1995) Molecular biology of microbial ureases. Microbiol Rev 59:451-580

Mortensen BM, Haber MJ, DeJong JT, Caslake LF, Nelson DC (2011) Effects of environmental factors on microbial induced calcium carbonate precipitation. J Appl Microbiol 111:338-349

Mulligan CN, Yong RN, Gibbs BF (2001) Bioremediation technologies for metal-contaminated soils and groundwater: an evaluation. Eng Geol 60:193-207

Nassrallah-Aboukais N, Boughriet A, Laureyns J, Gengembre L, Aboukais A (1999) Stabilization of vaterite structure in the presence of copper (II) species: thermodynamic and spectroscopic studies. Chem Mater 11:44-51

Natarajan KR (1995) Kinetic study of the enzyme urease from Dolichos biflorus. J Chem Educ 72:556-557

Ng SW, Lee ML, Hii SL (2012) An overview of the factors affecting microbial-induced calcite precipitation and its potential application in soil improvement. World Acad Sci Eng Technol 62:723-729

Nielsen TH, Bonde TA, Sorensen J (1998) Significance of microbial urea turnover in N cycling of three Danish agricultural soils. FEMS Microbiol Ecol 25:147-157

Okwadha GDO, Li J (2010) Optimum conditions for microbial carbonate precipitation. Chemosphere 81:1143-1148

Okwadha GDO, Li J (2011) Biocontaminant of polychlorinated biphenyls (PCPs) on flat concrete surfaces by microbial carbonate precipitation. J Environ Manag 92:2860-2864

Omar $\mathrm{H}$, Arida H, Daifullah A (2009) Adsorption of ${ }^{60} \mathrm{Co}$ radionuclides from aqueous solution by raw and modified bentonite. Appl Clay Sci 44:21-26

Pan XL (2009) Micrologically induced carbonate precipitation as a promising way to in situ immobilize heavy metals in groundwater and sediment. Res J Chem Environ 13:3-4

Pan X, Wang J, Zhang D (2005) Biosorption of Pb(II) by Pleurotus ostreatus immobilized in calcium alginate gel. Process Biochem 40:2799-2803

Park SJ, Park YM, Chun WY, Kim WJ, Ghim SY (2010) Calcite-forming bacteria for compressive strength improvement in mortar. J Microbiol Biotechnol 20:782-788

Paulino AT, Minasse FAS, Guilherme MR, Reis AV, Muniz EC, Nozaki J (2006) Novel adsorbent based on silkworm chrysalides for removal of heavy metals from wastewaters. J Colloid Interface Sci 301:479-487

Perez-Marin AB, Ballester A, Gonzalez F, Blazquez ML, Munoz JA, Saez J, Meseguer Zapata V (2008) Study of cadmium, zinc, and lead biosorption by orange wastes using the subsequent addition method. Bioresour Technol 99:8101-8106

Perez-Perez Gl, Gower CB, Blaser MJ (1994) Effects of cations on Helicobacter pylori urease activity, release and stability. Infect Immun 62:299-302

Phillips AJ, Gerlach R, Lauchnor E, Mitchell AC, Cunningham AB, Spangler L (2013) Engineered applications of ureolytic biomineralization: a review. Biofouling 29:715-733

Pouget EM, Bomans PHH, Goos JACM, Frederik PM, de With G, Sommerdijk NAJM (2009) The initial stages of templatecontrolled $\mathrm{CaCO}_{3}$ formation revealed by Cryo-TEM. Science 323:1455-1458

Puyen ZM, Villagrasa E, Maldonado J, Diestra E, Esteve I, Sole A (2012) Biosorption of lead and copper by heavy-metal tolerant Micrococcus luteus DE2008. Bioresour Technol 126:233-237

Qabany AA, Soga K, Santamarina C (2012) Factors affecting efficiency of microbially induced calcite precipitation. J Geotech Geoenviron Eng 138:992-1001

Qian CX, Wang JY, Wang RX, Liang C (2009) Corrosion protection of cement-based building materials by surface deposition of $\mathrm{CaCO}_{3}$ by Bacillus pasteurii. Mater Sci Eng, C 29:1273-1280

Qian C, Wang R, Cheng L, Wang J (2010) Theory of microbial carbonate precipitation and its application in restoration of cement-based materials defects. Chin J Chem 28:847-857

Radojevic M, Bashkin VN (1999) Practical environmental analysis. Royal Society of Chemistry, Cambridge 
Ramachandran SK (2007) Performance characteristics of bacterial concrete-a smart biomaterial. In: Proceedings of the first international conference on recent advances in concrete technology (Washington, DC), pp 67-78

Ramachandran SK, Ramakrishnan V, Bang SS (2001) Remediation of concrete using micro-organisms. ACI Mater J 98:3-9

Ramanan R, Kannan K, Sivanesan SD, Mudliar S, Kaur S, Tripathi AK, Chakrabarti T (2009) Bio-sequestration of carbon dioxide using carbonic anhydrase enzyme purified from Citrobacter freundii. World J Micribiol Biotechnol 25:981-987

Rawat N, Mohapatra PK, Lakshmi DS, Bhattacharyya Manchandra VK (2006) Evaluation of a supported liquid membrane containing a macrocyclic ionophore for selective removal of strontium from nuclear waste solution. J Membr Sci 275:82-88

Rivadeneyra MA, Ramos-Cormenzana A, Delgado G, Delgado R (1996) Process of carbonate precipitation by Deleya halophila. Curr Microbiol 32:308-313

Rivadeneyra MA, Delgado G, Ramos-Cormenzana A, Delgado R (1998) Biomineralization of carbonates by Halmonas eurihalina in solid and liquid media with different salinities: crystal formation sequence. Res Microbiol 149:277-287

Rodriguez-Navarro C, Rodriguez-Gallego M, Ben Chekroun K, Gonzalez-Munoz MT (2003) Conservation of ornamental stone by Myxococcus xanthus induced carbonate biomineralization. Appl Environ Microbiol 69:2182-2193

Rodriguez-Navarro C, Jimenez-Lopez C, Rodriguez-Navarro A, Gonzalez-Munoz MT, Rodriguez-Gallego M (2007) Bacterially mediated mineralization of vaterite. Geochim Cosmochim Acta 71:1197-1213

Rodriguez-Navarro C, Jroundi F, Schiro M, Ruiz-Agudo E, Gonzalez-Munoz MT (2012) Influence of substrate mineralogy on bacterial mineralization of calcium carbonate: implications in stone conservation. Appl Environ Microbiol 78:4017-4029

Rout TK, Sengupta DK, Kaur G, Kumar S (2006) Enhanced removal of dissolved metal ions in radioactive effluents by flocculation. Int J Miner Process 80:215-222

Sanchez-Navas A, Martin-Algarra A, Rivadeneyra MA, Melchor S, Martin-Ramos JD (2009) Crystal-growth behavior in CaMg carbonate bacterial spherulites. Cryst Growth Des 9:2690-2699

Sanchez-Roman M, Rivadeneyra MA, Vasconcelos C, McKenzie JA (2007) Biomineralization of carbonate and phosphate by moderately halophilic bacteria. FEMS Microbiol Ecol 61:273-284

Sarada D, Choonia HS, Sarode DD, Lele SS (2009) Biocalcification by Bacillus pasteurii urease: a novel application. J Ind Microbiol Biotechnol 36:1111-1115

Sarikaya M (1999) Biomimetics: materials fabrication through biology. Proc Natl Acad Sci USA 96:14183-14185

Sharma A, Bhattacharya A (2010) Enhanced biomimetic sequestration of $\mathrm{CO}_{2}$ into $\mathrm{CaCO}_{3}$ using purified carbonic anhydrase from indigenous bacterial strains. J Mol Catal B Enzym 67:122-128

Shen Q, Wang L, Huang Y, Sun J, Wang H, Zhou Y, Wang D (2006) Oriented aggregation and novel phase transformation of vaterite controlled by the synergistic effect of calcium dodecyl sulfate and n-pentanol. J Phys Chem B 110:23148-23153

Siddique R, Achal V, Reddy M, Mukherjee A (2008) Improvement in the compressive strength of cement mortar by the use of a microorganism—Bacillus megaterium. In: Limbachiya MC, Kew H (eds) Excellence in concrete construction through innovation. Taylor \& Francis, London, pp 27-30

Silver S, Toth K, Scribner H (1975) Facilitated transport of calcium by cells and subcellular membranes of Bacillus subtilis and Escherichia coli. J Bacteriol 122:880-885

Singh S, Eapen S, Thorat V, Kaushik CP, Raj K, D'Souza SF (2008) Phytoremediation of ${ }^{137}$ cesium and ${ }^{90}$ strontium from solutions and low-level nuclear waste by Vetiveria zizanoides. Ecotoxicol Environ Saf 69:306-311

Smith RW, Fujita Y, Ferris GF, Cosgrove DM, Colwell RS (2004) Trace metals in groundwater \& Vadose zone calcite: In situ contaminant \& stabilization of ${ }^{90}$ strontium \& other divalent metals \& radionuclides at arid west DOE sites. USDOE Office of Science, Technical Report, OSTI ID: 839261

Soon, NW, Lee LM, Khun TC, Ling HS (2014) Factors affecting improvement in engineering properties of residual soil through microbial-induced calcite precipitation. J Geotech Geoenviron Eng 140. doi:10.1061/(ASCE) GT.1943-5606.0001089

Soon NW, Lee LM, Khun TC, Ling HS (2013) Improvements in engineering properties of soils through microbial-induced calcite precipitation. KSCE J Civ Eng 17:718-728

Spanos N, Koutsoukos PG (1998) The transformation of vaterite to calcite: effect of the conditions of the solution in contact with the mineral phase. J Crystal Growth 191:783-790

Stabnikov V, Naeimi M, Ivanov V, Chu J (2011) Formation of water-impermeable crust on sand surface using biocement. Cem Concr Res 41:1143-1149

Stabnikov V, Jian C, Ivanov V, Li Y (2013) Halotolerant, alkaliphilic urease-producing bacteria from different climate zones and their application for biocementation of sand. World J Microbiol Biotechnol 29:1453-1460

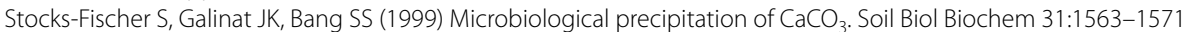

Suh JH, Kim DS, Yun JW, Song SK (1998) Process of $\mathrm{Pb}^{2+}$ accumulation in Saccharomyces cerevisiae. Biotechnol Lett 20:153-156

Tai CY, Chen FB (1998) Polymorphism of $\mathrm{CaCO}_{3}$ precipitated in a constant-composition environment. AlChE J 44:1790-1798

Thompson JB, Ferris FG (1990) Cyanobacterial precipitation of gypsum, calcite and magnesite from natural alkaline lake water. Geology 18:995-998

Tobler DJ, Cuthbert MO, Greswell RB, Riley MS, Renshaw JC, Sidhu SH, Phoenix VR (2011) Comparison of rates of ureolysis between Sporosarcina pasteurii and an indigenous groundwater community under conditions required to precipitate large volumes of calcite. Geochim Cosmochim Acta 75:3290-3301

Tourney J, Ngwenya BT (2009) Bacterial extracellular polymeric substances (EPS) mediate $\mathrm{CaCO}_{3}$ morphology and polymorphism. Chem Geol 262:138-146

Tripp BC, Smith K, Ferry JG (2001) Carbonic anhydrase: new insights for an ancient enzyme. J Biol Chem 276:48615-48618

Van Langerak EPK, Hamelers HVM, Lettinga G (1997) Influent calcium removal by crystallization reusing anaerobic effluent alkalinity. Water Sci Technol 36:341-348

Van Paassen LA, Daza CM, Staal M, Sorokin DY, van der Zon W, van Loosdrecht MCM (2010) Potential soil reinforcement by biological denitrification. Ecol Eng 36:168-175 
Vandevivere P, Baveye P (1992) Relationship between transport of bacteria and their clogging efficiency in sand columns. Appl Environ Microbiol 58:2523-2530

Volesky B (2001) Detoxification of metal-bearing effluents: biosorption for the next century. Hydrometallurgy 59:203-216 Vullo DL, Ceretti HM, Daniel MA, Ramirez SAM, Zalts A (2008) Cadmium, zinc and copper biosorption mediated by Pseudomonas veronii 2 E. Bioresour Technol 99:5574-5581

Wakayama H, Hall SR, Mann S (2005) Fabrication of $\mathrm{CaCO}_{3}$-biopolymer thin films using supercritical carbon dioxide. J Mater Chem 15:1134-1136

Wang J, Chen C (2009) Biosorbents for heavy metals removal and their future. Biotechnol Adv 27:195-226

Wang X, Ruchenstein E (1993) Preparation of porous polyurethane particles and their use of enzyme immobilization. Biotechnol Prog 9:661-665

Warren LA, Maurice PA, Parmar N, Ferris FG (2001) Microbially mediated calcium carbonate precipitation: implications for interpreting calcite precipitation and for solid-phase capture of inorganic contaminants. Geomicrobiol J 18:93-115

Warthmann R, van Lith Y, Vasconcelos C, McKenzie JA, Karpoff AM (2000) Bacterially induced dolomite precipitation in anoxic culture experiments. Geology 28:1091-1094

Wei H, Shen Q, Zhao Y, Wang D, Xu D (2003) Influence of polyvinylpyrrolidone on the precipitation of calcium carbonate and on the transformation of vaterite to calcite. J Cryst Growth 250:516-524

Whiffin VS, van Paassen LA, Harkes MP (2007) Microbial carbonate precipitation as a soil improvement technique. Geomicrobiol J 24:417-423

White CM, Strazisar BR, Granite EJ, Hoffman JS, Pennline HW (2003) Separation and capture of $\mathrm{CO}_{2}$ from large stationary sources and sequestration in geological formations-Coalbeds and deep saline aquifers. J Air Waste Manag Assoc 53:645-715

Wold JD (1994) Soil solution chemistry: applications to environmental science and agriculture. Wiley, New York Worrel E, Price L, Hendricks C, Meida LO (2001) Carbon dioxide emission from the global cement industry. Annu Rev Energy Environ 26:303-329

Xu X, Han JT, Kim DH, Cho K (2006) Two modes of transformation of amorphous calcium carbonate films in air. J Phys Chem B 110:2764-2770

Yadav R, Labhsetwar N, Kotwal S, Rayalu S (2011) Single enzyme nanoparticle for biomimetic $\mathrm{CO}_{2}$ sequestration. J Nanopart Res 13:263-271

Yamamura S, Ike M, Fujita M (2003) Dissimilatory arsenate reduction by a facultative anaerobe, Bacillus sp. strain SF-1. J Biosci Bioeng 96:454-460

Yoshida N, Higashimura E, Saeki Y (2010) Catalytic biomineralization of fluorescent calcite by the thermophilic bacterium Geobacillus thermoglucosidasius. Appl Environ Microbiol 76:7322-7327

Yu HQ, Tay JH, Fang HH (2001) The roles of calcium in sludge granulation during UASB reactor start-up. Water Res 35:1052-1060

Zhang Z, Lian B, Hou W, Chen M, Li X, LiY (2011) Bacillus mucilaginosus can capture atmospheric $\mathrm{CO}_{2}$ by carbonic anhydrase. Afr J Microbiol Res 5:106-112

\section{Submit your manuscript to a SpringerOpen ${ }^{\circ}$ journal and benefit from:}

- Convenient online submission

- Rigorous peer review

- Immediate publication on acceptance

- Open access: articles freely available online

- High visibility within the field

- Retaining the copyright to your article

Submit your next manuscript at $\mathbf{s p r i n g e r o p e n . c o m ~}$ 